\title{
A METHODOLOGICAL STUDY OF SEX STEREOTYPES
}

\author{
By \\ MARGTE IOUISE COWAN, \\ Bachelor of Arts \\ Louisiana Tech University \\ Ruston, Louisiana \\ 1970
}

Submitted to the Faculty of the Graduate College of the Oklahoma State University

in partial fulfiliment of the requirements

for the Degree of

MAS TER OF SCI ENCE

July, 1972 
Thesin

1972

$C 874 \mathrm{~m}$
cop. 2 
OKLAHOMA

GATE UAHERS

I IRPARY

FEB 51973

A METHODOLOGICAL STUDY OF SEX STEREOTYPES

Thesis Approved:

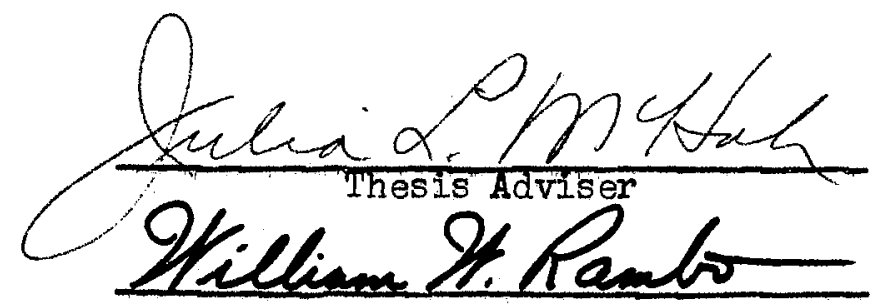

Cartwee 9 Taines

$\frac{\text { Dhurhani }}{\text { Dean of the craduate college }}$

836807 


\section{ACKNOWLEDGMENT}

To the faculty and students of the Center for Social Psychological Studies, I would like to express my gratitude for the exposure to different ideas and techniques of research. It was the hours spent in association with these people that enabled me to design and conduct this research.

To my committee special appreciation is due for the time spent in the planning and analysis stages of the research. I would like to acknowledge the role my chairman, Dr. Julia McHale, performed in limiting the scope of this research and thus, making it a workable thesis. For his suggestion of the Lawshe-Baker Nomograph, I am especially grateful to Dr. William Rambo. To Dr. Barbara Weiner, I am deeply appreciative for the interest and many hours of consultation.

To my parents, special thanks for a day on the beach when I needed the break. 
TABLE OF CONTENTS

Chapter

Page

I. THE II TERATURE REVIEW 。. . . . 。 . . . . . I

The Purpose of the Study............ 1

History of Sex Stereotypes ............ 3

Conclusions Drawn from Literature . . . . . . 17

Statement of Hypotheses .......... 18

II. METHODOLOGY . . . . . . . . . . . . . . 20

Phose I: Collection of Stereotypic Items . . . . . 20

Phase II. Validation of the Stereotypic Items... . 24

III. RESULIS . . . . . . . . . . . . . . . 27

Collection of Stereotypic Items . . . . . . . 27

Volidotion of the Stereotypic Items . . . . . . 35

IV. DISCUSSION AND CONCLUSIONS ............ 44

Collection of Stereotypic Items . . . . . . . . 44

Validotion of the Stereotypic Items . . . . . . 46

Visual Imagery . . . . . . . . . . . . . . . . 47 .

Implications of the Reserrch . . . . . . . 48

V. SUMMARY . . . . . . . . . . . . . . . 50

SELECTED BIBLIOGRAPHY . . . . . . . . . . . . 52

APPENDIX A . . . . . . . . . . . . . . 55

APP ENDIX B ..................... 58

APPENDIX C .................... 66

APPENDIX D.................... 68

APPENDIX E ....................... . 70

APPENDIX F . 。 . . . . . . . . . . . . 。. . . . 77

APPENDIX G . . . . . . . . . . . . . . . . . . 80

APP ENDIX H 


\section{IIST OF TABLES}

Table

Page

I. Adjectives on the Checklist Reaching Criterion . . . 28

II. Frequency of Subjects' Responses for Checklist Items Exhibiting Sequence Effects ........... 29

III. Frequency of Subjects' Responses for Checklist I tems Exhibiting Sex of Subject Effects ........ 29

IV. Differentiating Items of the Stereotype Questionnaire. - 31

V. Percent of Subjects Including Most Frequently Used Adjectives in Open-Ended Descriptions: Physical

Traits....................

VI. Percent of Subjects Including the Most Frequently Used Adjectives in Open-Ended Descriptions: Personality-

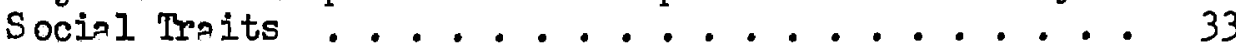

VII. Total Number of Different Adjectives Used in OpenEnded Descriptions ............. 33

VII. Frëquency of No Imagery by Sex of Subject, Stimulus, and Instrument .............. 34

IX. Frequency of Subjects' Responses Regarding the Relationship of the Imagery Person ........ 35

X. Percent of Responses for Question of Sex of Stimulus Description with Confidence Ratings of $60 \%$ to $100 \%$. . 36

XI. Percentäge of Subjects Responding to Esch Alternative for Validation Questionnaire . . . . . . . 38

XII. Percent of Imagery Reported by Response on Attribution of Sex of the Stimulus Description......... 41

XIII. Contingency Table for Response, Imagery, and Confidence of Response for Sex of Stimulus Description . . . . 42 
CHAPTER I

THE IITERATURE REVIEW

The Purpose of the Study

In the complexities of dally living, the vast quantity of input that the sensory system processes gives rise to the probability that some information will be lost in the encoding as well as the mediation of the output. The implication of this for the perception of people and events is that same individuality and uniqueness is lost to the perceiver. To be capable of handling as mach of the sensory field as possible, the individual tends to use categories, i.e. to group certain stimuli together. From these categorical processes, the perceiver teases out useful generelizations about the relationship among these grouped stimuli. All people use categories to some extent in their perception of people and events; the extent to which categorles are used and the size of the categories vary for different persons. Bower (1970) in discussing linguistic encoding states that this becomes a preferred oncoding because it frees the cognition from imme. diate sensory impression and concreteness of experience, thereby allowIng more abstract groupings to be used in structuring the diversity in direct experience. The course of development my lead to gradual withering away of imaginal processes. Visual impressions are no longer remembered in full, vivid richness, but rather become conventlonalized in terms of conceptual stereotypes. 
Social stereotyping can be defined as the general inclination to place persons in categories according to some easily and quickly identifiable chargcteristics and then to attribute certain qualities as typical of members of that group. Vinacke (1956) viewed stereotyping as a conceptaal process whose crucial aspect is the involvement of personality traits as well as the physical traits in the formation of the concept. Extending this view, stereotyping becomes an inevitable consequence of social learning whereby individuals are classified on the basis of perceptual properties thus facilitating for the perceiver meaningful responses to these individuals. As a categorical process, stereotyping of persons serves an adeptive, perhaps essential, function for the perceiver.

The purpose of this thesis was to exemine more closely a specific area of social stereotyping, that of sex stereotypes. The existence of sex stereotypes has been a consistent and well documented finding in the psychological literature over the past thirty years. Two factors, however, necessitates a reevaluation of work in the aree of sex stereotyping research. One is the recent criticisms and suggestions directed toward the methods and procedures used in stereotyping research in general (Brigham, 1971; Ehrlich and Rinehart, 1965). Secondly there has been in the last decade an emphasis on now views, attitudes, and approches to sex differences and sex roles. This influence needs to be evaluated. These above factors, the history of sex stereotyping research will be discussed largely in terms of methodological problems since it is these problems that this thesis was designed to investigate. 
History of Sex Stereotypes

The social scientist has not been hesitant in his study of stereotypes to focus on the negative connotation of the process that has developed. Even the man who introduced the concept of stereotyping, Walter Lippmann, was clear in his criticisms of the process as undesirable because of the incorrect content of the stereotype (Lippmann, 1922). Along this same line, Campbell (19.67) discussed the commonly accepted idea that stereotypes of group differences are false and thus implicitly that all groups are identical. He continued to point out, however, that the overall erroneous of stereotypes can be outlined without claiming that all groups are identical. Briefly Campbell mentioned four possible sources of errors found in stereotypes. The first is the phenomenal absoluteness of the ingroup members imagery of the outgroup or target object. An awareness that one's own preoccupetions contribute projectively to the content of the perception and, thus, invalidating the image, is lacking in stereotyping. Ano other source of error is the exaggeration of the homogeneity with which the ingroup or outgroup possess the attribute in question. There is a terdency to underestimate the amount of overlap between the ingroup and the target object. $A$ third error of stereotyping is an erroneous causal attribution by the perceiver. Race or sex rather than environmental influences are seen as causes for group differences. Finally, Campbell viewed the most important source of error as the relationship of the content of the stereotype and the hostility felt toward the group. The naive observer perceives the outgroup's differ. ent chargeteristics as causing his hostility; if it were not for these 
despicable traits, the outgroup would be loved. The soclal scientist, however, sees the hostility as existing first; then in service of the hostility all the possible differences are seen as despicable. As Campbell notes, "So flexible is our emotional language that a difference in almost any direction can be anathematized" (1967, p.825)。 The social scientist, as previously mentioned, has tended to approch stereotyping as inappropriate because of the inherent errors in the process. Yet as Brigham (1970) pointed out, criteria for assessing the degree to which the stereotype has met these standards of Inappropriateness have been for the most part unavailable. Given these possible sources of error in the process of categorical perception and the awareness that the possibility exists, overcoming such enculturation becomes a deeply experienced revelation. In the attempt to communicate such a revelation, it becomes probable that the experiencer becomes somewhat overzealous and vague in his criterion. This raises the same question that Brown (1958) asked:

Is it possible that the social psychologist has used the word stereotype to stigmatize beliefs of which he disspproves but which he does not know to be false? Has he perverted his science to achieve a moral purpose? (p. 366)

Further questions arise when this attitude is carried over into the methodological approaches to stereotyping。 Katz and Braly's (1933) paradigm of the adjective checklist has been the most frequently used method in stereotyping research. Criticism has been directed, however, at findings from such studies in that they have created someo what unrealistic accounts of the distribution, acceptance, and content of racial or ethnic stereotypes (Ehrich and Rinehart, 1965). These authors attribute two types of errors in using the adjective checklist 
In studying intergroup imagery. First, answers or responses so obtained fail to permit the reserrcher to distinguish between the subject's knowledge of the group's stereotype and his own personal endorsement. Sscond, it fails to tap the salient and personal aspects of the subject's intergroup Imagery. Fhrilch and Rinehart fur ther state:

Verbal expressions of opinions, including those called national sterootypes, may be oither sponteneous, that is for some reas on thought desirable or appropriate or it may be provoked or elicited for the purpose of resesrch...Purpase of sclentific technique is not to create new stereotypes in respondents, it is only to diso cover the already existent ones. It is not always certain that they succeed in doing so (1965, p. 565).

If the social scientist had a moral purpose in stadying ethnic stereotyping, even a greater objectivity and ceution is expedient in relation to sex stereotyping research. The imagery of sex stereotypes has implications for a wide range of social structures: family, vocation, and even the health fields. Since attitudes toward sex and sex roles form mxch of the core of the self-concept, a self-fulfilling prophecy phenomena in the research on sex stereotypes is very probable. Research is necessery to discover the already existing stereotypes, not to create new ones or to measure a subject's knowledge of a pres existing societal stereotype. It is here that Whrlich and Rinehart's (1965) criticisms on methodology has much pertinence for sex stereotyping rosearoh.

In swrveying the research done on sex stereotyping two points should be kept in mind whlle formaliting any conclusions. The first is the comparative scareity of strades specifieally dealing with sex 
stereotypes, perhaps less than 20 in the last 30 years. More important is the small number of resenrchers involved. Ten studies will be reviewed which ean be considered as stersotipic resoarch. Six of these were done by only two reserch tsims. In the $1950 \mathrm{ls}$, Sherriff and his asocia tes at the Univergity of Callfornla produced four studies reiating to sex tereotypes (Sherriff and Jarrett, 1953; Sherriff and MoKe日, 1957; MeKee and Shorriff, 1957; MeXeo and Sherriff, 1959). The other term is Rosenkrantig and his associatos whose work first began in 2968. The work of these two teaks constitutes the greater percentage of researeh on sex stereotypes.

A second point is that, with few exeeptions, studies on sex stereotypes have been done in a college setting with college students, usually introductory psychology strudents, who wer $\theta$ ins tructed to describe males, fem les, and self。 Two recent exceptions will be reported In this paper (Jenkin and Vroegh, 1969; Clarkson, Vogel, Broverman, Broverman and Hesenkrantz, 1970)。 Since college students in general gre not a truly random sample of the population generalized to, further doubts must be raised concerning the validity of sex stereotypes formed from responses of such sample. There are two Ideas involved in this comment. The first is that it is well accepted that sex and sex roles and expectations are more salient aspects of the college student's Iife. Intherent in any atudy dealing with sex and sex stereotyping are such demend charke teristim as be normal or at less to do not be abromal. The second Idea is the problem that college stadents must hare formedis derived or adopted ster eotypic ideas from some auree. To date this componerst of stereotypes has 
es caped study. No Iongitudinal stadies exist which give any indication of the development of chenge in stereotypes held about sex differences or sex roles. Developmental psychologiste proride some information about sex preference and 1dentifin ton but it is not known if stereotyping is simizer process. Wuch related work in terms of sex roles has been done in the last decade, yet littie la directly connected with stereotyping. The recent criticisms of ethnie stereotyping res search have not yet been integrated into the methodologies of sex stereotypes (Brigham, 1971; Campoll, 1967; Enriloh and Rinehart, 1965)。

Psychological literature on sex stereotyping began appearing sporadically in the 1940's. (In terme of total gestalts the increased numbers of women in jobs previously held by men during the second World War can be considered as a possible reason.) Fernberger's (1948) study on the persistence of stereotypes concerning sex differ ences set the tone for research findings to follow. These findings appear to be that males have superiority in almost all categories.

AIthough the theoretical comments in Sherriff and Jarrett (1953) are thoughtoprovoking their method, as is Diamond's (1955), is someo what disccuraging. These two studies used an instrument which consisted of a series of statements that the subjest was to identify as being more characteristic of mas or lemales. A neutral or undecided response was permitted in the Diamond study and scored as a half choice for each sex. The inter esting point abcut the reutral response was that it became necessary to completely discard some of the data for subjec ts whe used the response alnos texclusively. Diamond felt the response of neutral was "doubtless in a militant defense of sexul 
equality" (1955, p. 385). Furthermore, the criterion used to establish a stereotypic response were not clearly stated.

Sherriff and Jarrett (1953) had prejudged the itens in their Instruments. Seventeen were found to be le cultural stereotypes and 17 were female stereotypes; the remaining 24 items were judged to be irrelevant to cultural stereotypes. Half of all itens were seen as favorable and half as unfavarable. Significant differences were obtained as well as a preferenee for the male stereotypic items. This study contains more information regarding the formation of stereotypes than does the more recent literature.

Subjects learn that there are a number, perhaps relatively small number, of rather general traits which characterize behavior of men (women). This learning may be by way of direct personel experience with men and women (this is perhaps most important route) though for other attitudes this might be so, or by way of experience with verbalized beliefs and sttitudes of their associates. In either case each of the behaviors or attributes on our list is related by association with one or more of these general traits and by way of association also associated with either men. or wonen. It is this pattern of general traits which properly constitutes the stereotype (Sherriff and Jarrett, 1953, p.161)。

The findings from this study on sex differences in attitudes led to further studies by Sherriff and MeKee. The first of these is the differential evaluation aspect of stereotyping of sex differences (McKee and Sherriff, 1957) and a second deals with the qualitetive aspects (Sherriff and McKee, 1957). Since the methodology of the two are essentially the same, the discussion will treat them as one study. A rating scale was employed to messure the subject's view of the relative overall general woth, merit, or value of men and women. The question posed was whether a neutral point on the scale mede a differ- 
ence in the ratings. Inderd, aighly algalfioant difference in the eveluations of six point as opposed to a seven point vas found. With the noutral polnt, subjeot expresed equalitarian feelingo or attitudes. Whethe this wa moratid indiotion of the subjectio true attitudes or an artifect of the instrument and the opportunity to exprese more ocleliy desirablo postiton is loft unenswer.

The authors used Sarbln's afoctive checklist consisting of 200 1tems. Two different procedures wero adopted for use with the list,

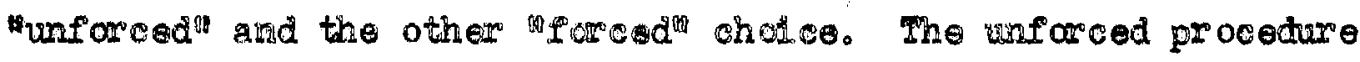
consisted of a card on which the ltems were printed and passed to the subjects. Subjects ware then told to oneck thase items which were in generally true of men (cromen)。: Half of the subjocts began with men and half with wamen. After linishing the first card, a second card was glven to the subjects il the same instructions for the opposite sex. A third card was then given to a.1I subjects with the instructions to mark for esch litem whetherit it wes more chereoteristic of men or wonen. This portion of the procedure ites ared to as the forced choice. Note that the seme subjects underwent both conditions. In the first study dering with eraluation the correlaticn between the two procedures (based on preference shown for one sex) was w.64 for men and +.70 for wcmen subjects. This was for the seme subjects with no time lapso betwen tosting perrods. cenerwily, the fored ohoice

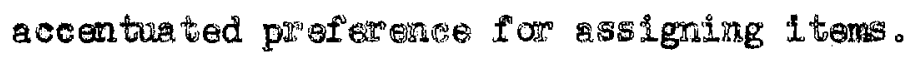

Sterpotype was defined by Sherrof and MoRee (1957) the bas is

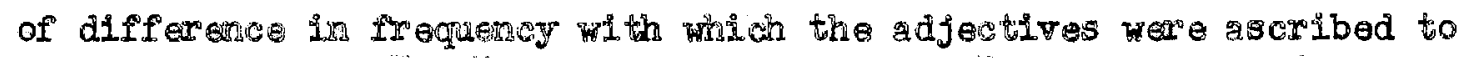
men and womer. Agaln terdercy to believe that sme things are mare charactexistic of cne group then of the other did occur. Using the 
criterion of Sherriff and Mckee two important conclusions emerge: (1) the method elimina tes adjectives which are ascribed to each sex equally of ten, even though the item may be high in frequency, and (2) It leads to the inclusion of items mentioned infrequently but which do show a difference in attribution. More mphasis was placed on the unforced cholce responses on the basis that:

$$
\begin{aligned}
& \text { ofreely ascribed characteristics are probably } \\
& \text { close to the central core of the stereotype; } \\
& \text { characteristics which subjects assign to one sex } \\
& \text { or the other only when forced to do so are pre } \\
& \text { sumably less salient and less strongly } \\
& \text { with the label (Sherriff and McKe日, 1957, p. 452). }
\end{aligned}
$$

Under the open-ended procedure followed in the two studies, subjects were told to list ten of the behaviors and characteristics of men and ten of women. FIrst, the traits were judged into categories

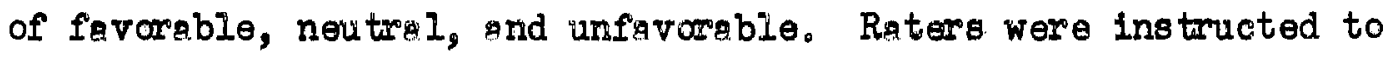
Judge the items as to the desirgblilty when gpplied to men and women. In the second study, these traits obta Ined under the openoended procedure were sorted into eategories. The only traits that emerged from the openanded procedure that were not comparable to those found in the adjective checklist were physica I attributes, orientation to home and hearth, and talkative。

Sherriff and McKee (1957) extended their study one fur ther step by asking whether the obtained stereotype was vilid, i.e. were the items that constiftuted the stereotypes of men and women equivalent to the items used by the subjects to describe themselves. Again the adjective checklist was used in which the subjects checked items thought to be characteristio of themselres. The most noticeable difference was the marked reduction of the number of items ascribed 
significently more of ten by one sex or the other. Instructions to describe men or womer in general is actually encouraging subjects to dismiss Individual differences and uniqueness while describing oneself tends to emphesize such individuality. Ihis is the explanation offered by Sherriff and MoKee to expla in the reduction in the number of items used. The opposite expectetion may be argued. If the individual differencel are dismissed, then the core structure of the character1sties of the therget group should remin. Then in taking into considerstion many subjocts desoribing themselves, there should be a definite Inorese in the number of Items employed to illus trate these Individual differences instead of a reduction as reported by Sherriff and McKee. Another alternative explanation is the subjects may not have been describing themselves as they perceived thoir uniqueness but rather were responding with socially desirable treits, which could result in a reduction of items used.

The conclusion reported is that projection is only part of the story of social stereotypes. To some extent stereotypes are a dis. tillation of cultural beliefs which have grisen from various sources.

Reality, of course, includes behaviors which result from conformity to culture I stereotypes as well as attributes with are naive. Just whet characteristics in the stereotype derive primerily from reality, which from projection, and hich from other sources is diffieult to say (Sherriffif and MoKee, 1957, p. 462)。

Another conclusion drawn from the dat was the significantly greater degree to which women described themselves in terms of the stereotypes of their own $s \in x$, both fryoroble and unfavorable. Items used by women centered around wht the authors called "women's neuroticismg (e.g。 passivedependence syndrome). What is still un. 
resolved is whether the finding implies a real difference between the sexes in personality, or a greater tendency for women to conform to social expectations.

More recently in the literature cliniclans have been examining the sex stereotypes, phrased however in terms of masculinity and femininity. Jenkin and Vroegh (1969) proposed that masculinity and fenininity are not a single bipolar variable but rather two separate continuums with masculinity having reference to males and femininity to females. An adjective checklist and semantic differential were used as instruments. Endorsement by 66 percent of the respondents was set as criterion for designating an item as stereotypic. Six different stimuli were used, one of which was written at the top of each instrument. The stimuli were: (1) most males, (2) most femples, (3) most masculine person you can imagine, (4) most feminine person you can imagine, (5) least masculine person you can imagine, and (6) least feminine person you can imagine. A counterbalanced design was used for the persentation of the first two stimuli and the order of presentation of the instruments. The first two stimuli (males and females) were always presented first with a randomized order of the four remaining stimuli. Two points from this study are of importance to sex stereotyping research. The analysis of the semantic differential was done in terms of three factors; eviluative, potency, and activity. No other research has taken this approach in stereotyping. There were significant differences among the stimuli when each was separated by these three factors. An additional important finding is that masculinity and femininity elicit similar descriptions but distinct personality differences. The similarity in the two descriptions was that 
the items common to both sexes are items basically high in social desirability, 1.e. the social acceptability that both men and women enfoy.

The point of social desirability appears in Iunneborg (1970). The question she asked was how do we know when a masculinity-femininity scele assesses a person's own psychological masculinity-femininity and not his or her awereness of the correct stereotypic responses. Fourteen scales of the Edwerds Personality Inventory (EPI) were given to two different groups, one of which received the standard instructions for the EPI thus serving as a normative self-description group. The other group received the following introduction: "Many EPI items are answered in opposite directions by men and women. In order to refine the test, additional evidence of the sex stereotype of items is needed" (p. 13). Subjects were further Instructed not to describe themselves but rether predict the answers most women (men) would give in describing themselves. An important methodologicel question is whether another control group if asked to predict answers of men (women) would give similar responses if they did not recelve the Introduction set of stereotypic responses. Sex differences appeared on all but one scale as a result of the stereotypic instructions. The stereotypic responding exaggerated existing sex differences as show by the normative dato as well as created differences which were not acknowledged by the control group. Over half of the stereotypic items were in three scales: (1) conforms, (2) is a leader, (3) worries about making a good impression. Those scales truly discriminating the sexes in normative group were: (1) intellecturlly oriented, (2) has cultural interests, (3) is a leader.

Lunneborg concluded that knowing the degree and kind of a person's 
stereotypic thinking about masculinity-feminity is possibly the best correction for defensiveness in self-description. Of social desirability, Lunneborg stated that if a dimension which is generally recognized as differing between the sexes does not discriminate on a paper-pencil task, the probable explanation is that the dimension is socially desirable; thus both males and females claim trait possession. By the same reasoning, if an item is again a diacriminator between males and females but does not do so, it may be that the item is undesirable. Given the unforced situation, both groups may choose to ignore the item in their descriptions.

Social desirability plays a large role in the recent studies specificelly dealing with sex stereotyping by Rosenkrantz, Vogel, Bee, Broverman, and Broverman (1968) and by Broverman, Broverman, Clarkson, Rosenkrantz, and Vogel (1970). This team began with the assumption of existing sex stereotypes based on the past literature including that of Sherriff and Mckee. The purpose of the former paper was to examine the relation of self-concept to the differential valued sex stereom types. Broverman et al. (1970) extended this finding to clinical judgments on mental health and Clarks on et al. (1970) related sex role stereotypes to family size.

Beginning in 1968 the instrument used in research was the Stereow type Questionnaire developed by Rosenkrantz et al。(1968)。The Questionnire consisted of 122 items arranged in bipolar form with the poles separated by 60 points. Social desirability ratings were obtain. ed from independent semples who were told to indicate which pole of the item represented the more socially desired behavior for the population in general, not for one sex or the other. All subjects were given the 
Questionnaire in group sessions with the instructions "to imagine you are going to meet someone for the first time and the only thing you know in advance is that person is an adult male" (p. 288). Subjects marked each item as they thought it would characterize an adult male. After having finished, subjects were asked to do the same thing for an adult female. The third time subjects marked items as they thought characterized themselves.

Sex stereotyping implies extensive agreement among people as to characteristic differences between men and women. Seventy-five percent agreement was set by Rosenkrantz et 91 . (1968) as the criterion to indicr te the presence of a stereotype for sny given item. They found 41 of the 122 items to be stereotypic. As found in previous research, stereotypic masculine traits were perceived as socially desirable significantly more often than feminine traits. Despite the large significant differences between the means of the masculine and feminine responses, variations in both responses were a function of social desirability. Variations is responses, then, are sensitive to social desirability while differences in means reflect stereotypic notions of sex differences. The self-concepts of both men and women subjects were less extreme than the stereotypes for their sex, and as found in the stereotypes for men and women, the self-concepts scores were affected by social desirability。

The last two studies to be discussed are included for the applied purposes they illustrate rather than the methodological reasons. Broverman et. al. (1970) and Clarks on et al. (1970) reveal the vast implication stereotypes hold for people not only in perceptual pro. cesses but also in judgments and basic life decisions. In the study 
deeling with clinical judgments, clinlclans were glven the Stereotype Questionnaire under three stimulus conditions: female, male, and adult. Instructions were:

Think of a normal adult man (woman) and then indicate on each item the pole to which a mature healthy socially competent adult man (woman) would be closer (Broverman et. al。, 1970 , p.2).

For the adult condition sex was not mentioned. Only the 41 stereotypic items that Rosenkrantz et al. (1968) found as stereotypic were analyzed. The general findings were of a double health standard, i.e. general adult standards apply only to men; healthy women were perceived significantly less healthy in comparis on to the adult standard. Further, these differences were found for both mele and female clinicians, and parallelled the sex role stereotypes prevalent in present society. Thus what this study concluded for a woman to be considered healthy from an adjustment viewpoint she must adjust to and accept the behavioral norms of her sex even though these behaviors are generally less socially desirable and considered to be less healthy for a competent adult.

The general hypothesis of Clarkson et al。 (1970) was that a critical psychological factor affecting the number of children a woman desires and achieves is her acceptance or rejection of the feminine stereotypic social roles prevalent in our society (p.390)。The Ques. tionnaire was given to 96 mothers of college age men. Two self concept scores were obtained; responses to the male valued stereotypic items and those to the female items. The malesvalued pole described a rational competent mature individual which the authors labeled as the competency cluster; the femple as the warmth and expressiveness cluster. 
By dividing the group of women into a high and low competency groups, no differences were found in the level of educetion or the number of years worked. The high competency group, however, had significantly fewer children than the low group. In general it was shown that incorporation by women of the male-valued stereotaplc characteristics Implies an enhancement of the self-concept along a dimension of mental health, maturity, and self-actuelization.

Similar findings were reported by Rand (1968) in s study desling with college freshmen women. $A$ group of 848 freshmen were divided into two conditions on the besis of their reply to questions of whet they hoped to obtain from attending college. The American College Survey was the only instrument given to the women. The two groups were composed of one section who stated that finding a husband was their greatest expectation and the second, whose expectation was a higher degree e.g. MoD。, LLB, DDS, or PhD). The findings showed that those women who deviated from the traditional sex role expectations did possess more masculine traits and characteristics; thereby, redefining their sex role to include those characteristics and behaviors approw priate to both sexes in our culture.

\section{Conclusions Drawn from Literature}

The most frequent problems in stereotyping research center around the subjects' reactions to the instruments and the experimental set. ting. Sex of the subject serves as an experimentel variable in itself。 Sequence or order in which the subject describes male or female can be a problem. However, by counterbalancing the order for half the sample this problem is reduced. The problem of the instrument however, is 
not so easily solved. In a forced choice form, what the subject has to choose from will determine what responses are probable, even what responses are possible. The question of saliency and personal endorsement rather then mere acknowledgment of stereotypic items remain ques. tions to be answered. There rempins also the question of inherent dem and characteristics of requesting a subject to describe male and female adults. College students for the most part are sophisticated enough to hypothesize in such experiments that what the experimenter is looking for is a difference between males and females; whether he will be "good subject" and give that difference is perhaps the question most stereotyping research is really measuring (Rosenthal, 1961; Orne, 1961).

Recent applied work in sex stereotyping shows the vast implication that sex roles and expectations do have in functioning in the society. Social psychologists and clinicians have an important role to perform in the study of stereotypes in relation to interacting with those people who come seeking help in this area of their social functioning. However, there still remain unanswered questions about the why and hows of stereotypes and techniques still undeveloped or at least not in use to answer these questions. It is the purpose of this research to examine more closely some of the methodological problems in sex stereotyping in the hope that what will be learned can help in relating to people about sex differences and sex role expectations.

\section{Statement of Hypotheses}

From conclusions drawn from the literature, it is hypothesized the t: 
(1) there will be a difference in tralt attribution to males and females,

(2) the set of stereotypic items for each Instrument will differ in content. In addition, the image projected by each instrument description will elicit different responses from subjects in the validation procedure,

(3) when responding, subjects are in fact describing someone specific and not some generalized conceptualization of male/fomale. 
CHAPTER II

METHODOLOGY

There were essentially two phases of date collection. Phase I was the collection of stereotypic items for the different instruments. Phase II was the validation of those 1tems. Since different subject samples and different procedures were used in the two pheses, the methodology of each phase will be presented separately.

Phrse I: Collection of Stereotypic Items

\section{Subjects}

Two hundred sixty-four undergraduate students in four different sections of Introductory Psychology at Oklahoma State University served as subjects ( $\underline{S}$ ). All Ss were randomly assigned to one of twelve cell conditions giving 22 Ss per cell. These 12 conditions are described in the following section.

Design

The dependent variable was the Ss' responses to the following stimulus which was the same for male and female stimuli except for the pronoun gender.

Imagine you are going to meet someone for the first time and the only thing you know in advance is that he [She7 is an adult.

More specifically, the variable was the proportion of Ss responding to 
Items of the instruments under the 12 conditions. There were three Independent variables menipulated; sex of $S$, sequence of stimulus presentetion, and the instrument used. The instrument wos the variable of primary interest. Sex of $\underline{S}$ and sequence affects were examined separately for each instrument. An arbitrary criterion of less than five percent of the total items for an instrument showing sex of $\underline{S}$ or sequence affects was used as defining no sequence or sex of $\underline{S}$ affects for that instrument. If less than criterion showed affects, the cells for sex of $\underline{S}$ and sequence were collapsed yielding 88 Ss per instrument. The design consisted of two sequence combinations (male lst - female 2nd and female lst - male 2nd), two sex of Ss, and three instruments.

\section{Instruments}

Three different instruments were used in the collection of sex stereotypes; the Adjective Checklist, Stereotype Questionnaire, and Open-Finded form. Different response styles were required by exch instrument. The Adjective Checklist developed by Gough and Heiburn (1965) consists of 300 items. A copy of the Checklist is found in Appendix A. Subjects were instructed to circle those items on the Checklist which the $\mathrm{S}$ chose in describing the stimulus person. In filling out the Checklist, if a tralt were present in the description of the stimulus, the $\underline{S}$ circled it; if not, no response was made to the item on the form.

The second instrument used was the Stereotype Questionnaire devised by Rosenkrantz et $a l$ (1968) In its short form which contains 82 items (See Appendix B). The Questionngire is more of a forced choice form than the other instruments used. Subjects are "forced" into re- 
sponding quantatively to exch item along a serle of 10 to 70.

For the third instrument, simple open-ended formet was used in which the $\underline{S}$ s asked to describe the stimulus person. Nothing else appeared on the page except the request for the description. This was the most unstructured form and it was assumed any description given by a $\underline{S}$ would be salient for that $\underline{S}$.

Following the completion of one of the above instruments each $\underline{S}$ responded to a set of questions dealing with visual imagery exper lenced while the $\mathbf{S}$ was describing the stimulus person (See Appendix D). These questions were included to obtaln some information as to whether Ss were responding in terms of a generalized conceptualization of malewemle or if some specific person was being described.

Any one S received only one instrument which was in response booklet conteining a statement concerning the sex of the stimulus person. A response booklet was complied for each $\underline{\mathrm{S}}$ in each condition. The response booklet consisted of: (I) first set of instructions or first stimulus, (2) first copy of the instrument of that condition, (3) first copy of imagery questionnaire, (4) second set of instructions or second stimulus, (5) second copy of the same instrument, and (6) second copy of the imagery questionnaire. An example of the response booklet used in the open-ended procedure can be found in Appendix E.

The subtle stimuli of the pronouns he and she and the two copies of the instruments were used in order to reduce the demand character. istics of a direct contrast of male and female. By responding on a second form the $\underline{S}$ is not confronted overtly with his first set of responses and thus experiencing the greater contrast if there were only one form for response of both male and female descriptions. 
Procedure

The collection of stereotypic Items was conducted in the class. room of the specific section of Introductory Psychology being tested. Response booklets hed been arranged so that no two identicel forms were given to Ss seated side by side. All date were collected the same dey by the same female experimenter. Subjects were given the following information before the booklets were distributed:
We are collecting reliability data on different instruments used in research on impression for- mation. To make it ensier and quicker to sort the data for machine scoring, we have color- coded the forms according to sex. Men, please take the white forms and women the green. Please fill out the forms completely, following the instructions given in the booklet. There are different instruments so some of you will finish before others. When you do finish check over your responses, making sure you answered all questions you intended to answer. You may leave when you finish.

Nothing else was said to the Ss. Booklets were collected as the $\underline{S}$ turned them in.

Dato Analysis

To test for sequence and sex of $S$ effects, item analyses using the Lawshe-Baker Nomograph were carried out for the Checklist and the Stereotype Questionnaire (Downie and Heath, 1965). The responses on the Openo Inded form were content analyzed and categorized into three dimensions: physical traits, personality-social traits, and work. If no sequence or sex of $\underline{S}$ affects were obtained, the data were combined for the instrument. A criterion of 40 percent consensus among the combined total $\mathrm{Ss}$ for an instrument had to be reached before an item 
wo $s$ included in the second phase.

\section{Phase II: Validation of the Stereotypic Items}

Subjects

Three different sections of Introductory Psychology not used in the collection phase provided the 180 ss for the validation of the stereotypes. There were $45 \mathrm{Ss}$ per condition in the four conditions. (As no sex differences were found in the collection phase, no attempt was made in the validation to consider sex of $S$ as a factor.)

Instruments

Only the Adjective Checklist and the Stereotype Questionnoire were used in this phase. As will be discussed in Chapter III, no item reached criterion on the Open. Ended form. The Questionnaire was marked with the mean scores for each item, i.e. the scale for exch item was marked with a slash on the mean number for that item for that stimulus. Two sets of forms were marked, one for male stimulus description and one for femsle stimulus description.

Two sets of the Checklist were marked; one for male and one for female stimulus description. All items which had been used by at least 40 percent of the collection sample in describing both male and female were circled on both the male and female forms. Then those items which differentiated mle and female stimulus at the .Ol level were marked on the appropriate sex form (See Appendix A, B, and F). There were, however, an exception to this criterion on the valice dation forms. On the Checklist, the adjectives masculine and feminine 
were not marked although they did definitely reached criterion. The Items "very mesculine" and "very feminine" on the Stereotype Questionnalre were onltted altogether from the validation form so that the form had only 80 items. It was felt by the experimenter that these items would be cues enough to elicit a response of male or femsle and It was the other stereotypes thet were of interest in the velidation phase.

A set of Il questions in multiple-cholce format were used to obtein the validation Informetion (See Appendix F for Validation Questionnaire). Of specific interest was question \#6 asking for the sex of the stimulus person. If the stereotypic items can be considered as valid reflection of pieces of information used to categorize people into male-femple, then there should be high percentage of correct responses for that form. Other questions served as filler questions and Incidental information.

Procedure

There was no specific information given to the Ss before receiving the questionnaire and the computer card on which the answers were directly recorded. Subjects responded only to one stimulus description. The group wes informed that they had an opportunity in which to participate in a psychological experiment for extra credit if they so desired. The vast mojority of the classes did participate. The ino structions on the questionnaire were as follows:

This is a second part of a study on Impression formation. We had previously asked a group of subjects to describe various people by filling out a response form. We would like you to study the responses on this attached form which were 
used to describe these different people. Then on the basis of these responses and your impression, please answer the following questions by marking the appropriate circle on the IBM card.

There were four different forms; Stereotype Questionnaire with $r e$ sponse marked for male stimulus, one marked for female, and the Checklist marked for male and one for female.

Data Analysis

Responses were scored by computer giving the number of Ss choosing the various alternative answers for the 11 questions. Tests for differences in proportions were done by the use of Lawshe-Baker Nomograph and Pearson Chi-Square. 


\section{CHAPTER III}

\section{RESULIS}

\section{Collection of Stereotypic Items}

The hypothesis of difference in trait attribution to male and femele stimuli wa supported for the instruments, Adjective Checklist and Stereotype Questionnaire. Differences in traits for male and femple stimuli were not obtained in the open-ended procedure.

\section{Adjective Checklist}

A test for correlated proportions (Damie and Heath, 1965, p. 151) was used to determine differentiation in items attributed to male and female stimuli. The test revealed 11 ltems that were attributed to males significantly more of ten than to females; 11 items were also used more often in describing females than in describing males. Table I contains those items which differentiate male and female stimuli at the .01 level of significance and which are also endorsed by at least 40 percent of the subjects for either male or female stimuli. Also found in the table are the 42 items used by a minimum of 40 percent of the subjects in their description of both male and female.

Although fewer items than would be expected by chance were found to exhibit sequence or sex of subject effects at the .01 level, of the 12 items which did so, seven are stereotypic items. Tables II and III show these items with the frequency of the S's responses. 
The Item analysis for the Checklist is found in Appendix G. It should be noted in looking at the z-scores that there are items which differentiate males and females at the .Ol level of significance which ore not included in Table I. These items failed to resch the criterion of use by 40 percent of the sample.

TABLE I

ADJECIIVES ON THE CHECKIIST REACHING CRITERION

\begin{tabular}{|c|c|c|c|}
\hline MALE AND FEMALE & STMUII & MALE & FEMALE \\
\hline $\begin{array}{l}\text { Active } \\
\text { Alert } \\
\text { Appreciative } \\
\text { Calin } \\
\text { Capable } \\
\text { Charming } \\
\text { Clear-thinking } \\
\text { Clever } \\
\text { Considerate } \\
\text { Dependable } \\
\text { Eesy Going } \\
\text { Efficient } \\
\text { Energetic } \\
\text { Mnthusiastic } \\
\text { Fair-minded } \\
\text { Forgiving } \\
\text { Friendly } \\
\text { Generous } \\
\text { Good-looking } \\
\text { Good-na tured } \\
\text { Healthy } \\
\text { Helpful }\end{array}$ & $\begin{array}{l}\text { Honest } \\
\text { Humorous } \\
\text { Independent } \\
\text { Intelligent } \\
\text { Interests wide } \\
\text { Moture } \\
\text { Natural } \\
\text { Outgoing } \\
\text { Potlent } \\
\text { Reasonable } \\
\text { Relaxed } \\
\text { Reliable } \\
\text { Responsible } \\
\text { Self-confldent } \\
\text { Sensitive } \\
\text { Sincere } \\
\text { Sociable } \\
\text { Talkative } \\
\text { Thoughtful } \\
\text { Witty }\end{array}$ & $\begin{array}{l}\text { Adventurous } \\
\text { Aggressive } \\
\text { Ambitious } \\
\text { Confldent } \\
\text { Determined } \\
\text { Frank } \\
\text { Hands ome } \\
\text { Imaginative } \\
\text { Masculine } \\
\text { Practical } \\
\text { Strong }\end{array}$ & $\begin{array}{l}\text { Affectionate } \\
\text { Attrective } \\
\text { CheerfuI } \\
\text { Emotional } \\
\text { Feminine } \\
\text { Gentle } \\
\text { Kind } \\
\text { Pleasant } \\
\text { Soft-hearted } \\
\text { Warm } \\
\text { Understanding }\end{array}$ \\
\hline
\end{tabular}


TABLE II

FREQUENCY OF SUBJECTS ' RESPONSES FOR CHECKIIST

ITEMS EXHIBITING SEQUENCE EFFECTS

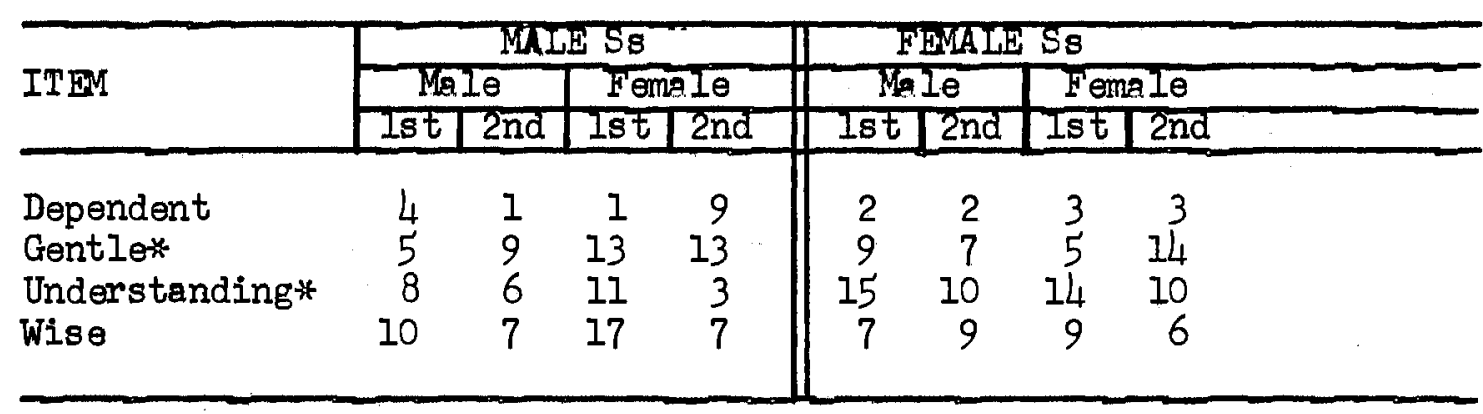

* female stereotypic item

$n=22$

TABLE III

FREQUENCY OF SUBJECIS' RESPONSES FOR CHECKIIST

ITEMS EXHIBITING SEX OF SUBJECT EFFECTS

\begin{tabular}{|c|c|c|c|c|c|}
\hline \multirow[b]{2}{*}{ ITEM } & & \multicolumn{2}{|c|}{ MALE S8 } & \multicolumn{2}{|c|}{ FEMLLE SS } \\
\hline & stImulus & Male & Tema le & Molo & Female \\
\hline \multirow{8}{*}{\multicolumn{2}{|c|}{$\begin{array}{l}\text { Affectionate* } \\
\text { Artistic } \\
\text { Attractive* } \\
\text { Cheerful* } \\
\text { Good-looking } \\
\text { Sexy } \\
\text { Strongt- } \\
\text { Understending }\end{array}$}} & 9 & 24 & $\mathrm{IL}_{4}$ & 12 \\
\hline & & 8 & 18 & 4 & 5 \\
\hline & & 13 & 37 & 26 & 30 \\
\hline & & 15 & 27 & 27 & 28 \\
\hline & & 21 & 30 & 29 & 17 \\
\hline & & 5 & 28 & 17 & 5 \\
\hline & & 15 & 6 & 29 & 8 \\
\hline & & 14 & 14 & 25 & 24 \\
\hline
\end{tabular}

* female stereotypic items

+ male stereotypic items

$n=44$ 
Stereotype Questionnaire

Data analysis was by the statistical procedure used by Rosenkrantz et 2 . (1968). For an item to be defined as stereotypic, the criterion z-score was set at the .01 level rether than the .001 as used by Rosenkrantz et al. Using this lower criterlon, only ten items were found to differentiate male and female stimuli. Six more items were stereptypic if the .05 level was used 78 criterion. Table IV presents these 16 items resching significance as differentiators. This number of stereptypic items is considerably lower than the 53 items that are reported a.s significant differentiators at the .001 level (Rosenkrantz et al., 1968; Broverman et al., 1970; Clarkson et. al., 1970).

There were only two items that were affected by sequence of stimulus presentation, items \#21 and \#64 (excitable in minor crisis and very ambitious, respectively). Both items were rated toward the desirable pole when female Ss rated female stimulus second rather than toward the undesirable pole as when the female stimulus was described first. No sex of subject affects were found.

The item analysis data in Appendix $H$ shows the mean responses for both male and female stimuli, the number of $M \supset F$ and F>M responses with the $\mathrm{z}-\mathrm{scores}$ for the items.

Open-Ended Instrument

For an item to be considered as stereotypic, it has to be used by at least 40 percent of the sample in the descriptions. As can be seen in Tables $V$ and VI no adjective in the open-ended procedure reached 


\section{TABLE IV}

DIFFERENTIATING ITEMS ON THE

S TEREOTYPE QUES TIONAAIRE

\section{ITEM}

DIRECIION

Not at all independent....Very dependent

$\mathrm{F}>\mathrm{M} * *$

Very emotional... Not at all emotional

Does not hide emotions... Almost always hides emotions

$M \gg F * * *$

Not at all excitable in major crisis...Very excitable in major crisis

Not at all skilled in business... Very skilled in business

Never cries...Cries very easily

Does not enjoy art and literature at all... Enjoys art and literature very much

Thinks men are superior... Does not think men are superior

Very masculine... Not at all masculine

$M>F * * * *$

Very feminine... Not at all feminine

$F \gg M * *$

$M \gg F * * * *$

$\mathrm{F}>\mathrm{M} * * *$

Always thinks before acting... Never thinks before acting

Dislikes moth and science very much... Likes math and science very much

Not at all excitable in minor crisis... Very excitable in minor crisis

$F \gg M * *$

$F \gg M * *$

$F>M * * *$

$M \gg F * * * *$

$F>M *$

$M>F *$

$\mathrm{F}>\mathrm{M} *$

Very gentle...Very rough

Very logical...Very illogical

$M>F *$

$F>M *$

Not at all restless... Very restless

$F>M *$ 
this criterion. There are small differences in the items used to describe male and female. The main difference in this open-ended condition is the difference in the percent of responses using the adjectives attractive, tall, and easy to talk to for male and female stimulus. In terms of the total adjectives used in the descriptions as can be seen in Table VII there was only a difference of four items. It was concluded from the results of the Open-Ended form that there were no stereotypic items elicited by the instructions.

From examining the Tables II through VII, it appears that the different instruments do produce different stereotypic items, the OpenFinded form producing no marked stereotypic items.

TABLE V

PERCENT OF SUBJECTS INCIUDING MOST FREQUENTLY

USED ADJECITVES IN OPEN-ENDED DESCRIPTIONS:

PHYSICAL TRAI TS

\begin{tabular}{lrll}
\hline \multicolumn{1}{c|}{} & \multicolumn{2}{c}{ FEMALE STIMULUS } & \multicolumn{2}{c}{ STIMULUS } \\
\hline Attractive & 5.6 & Attractive & 22.7 \\
Well-dressed & 17.0 & Well-dressed & 11.0 \\
Hair & 10.0 & Hair & 14.7 \\
Tall & 22.7 & Tall & 8.0 \\
Average Build & 6.8 & Average Build & 11.0 \\
& & Average Height & 11.0 \\
\hline
\end{tabular}


TABLE VI

PERCENT OF SUBJECTS INCLUDING THE MOST FREQUENTIY USED ADJECIIVES IN OPEN-ENDED DESCRIPIIONS:

PERSONAITTY-SOCIAL TRAITS

\begin{tabular}{|c|c|c|c|}
\hline MALE STIMULUS & & FEMALE STI & \\
\hline $\begin{array}{l}\text { Intelligent } \\
\text { Easy to talk to } \\
\text { Filendly } \\
\text { Basy to get along } \\
\text { Athletic } \\
\text { Polite } \\
\text { Mature } \\
\text { Likable } \\
\text { Educa ted } \\
\text { Considera te } \\
\text { Nice } \\
\text { Quiet }\end{array}$ & $\begin{array}{r}19.3 \\
13.6 \\
11.0 \\
8.0 \\
8.0 \\
6.8 \\
6.8 \\
6.8 \\
6.8 \\
5.6 \\
5.6 \\
5.6\end{array}$ & $\begin{array}{l}\text { Intelligent } \\
\text { Easy to talk to } \\
\text { Friendly } \\
\text { Easy to get along } \\
\text { Polite } \\
\text { Outgoing } \\
\text { Has good time } \\
\text { Personality } \\
\text { Knowledgable } \\
\text { Pleasant } \\
\text { Mature } \\
\text { Helpful } \\
\text { Kind }\end{array}$ & $\begin{array}{r}19.3 \\
19.3 \\
10.2 \\
5.6 \\
9.0 \\
9.0 \\
9.0 \\
8.0 \\
6.8 \\
6.8 \\
5.6 \\
5.6 \\
5.6\end{array}$ \\
\hline
\end{tabular}

TABLE VII

TOTAL NUMBER OF DIFFERENT ADJECIIVES USED

IN OPEN-ENDED DESCRIPTIONS

\begin{tabular}{l|c|c}
\hline \multicolumn{1}{c|}{ Dimension } & Male & Female \\
\hline Physical Traits & 12 & 12 \\
Personality_Social & 86 & 82 \\
Work & 9 & 9 \\
Total & 107 & 103 \\
\hline
\end{tabular}




\section{Imagery Questionnaire}

The data from the imagery questionnaire supports the hypothesis that $\mathrm{S}$ describe specific persons when responding to the male and female stimuli. Using Perason's Chi-Square to test for the difference between expected and observed frequency of reported imagery, a signiflcant Ch1-Square was found beyond the .01 level $\left(x^{2}=41.4\right.$, df -1$)$. As the Chi-Square indicates, significantly more $S$ s were thinking or visualizing specific persons while responding to the male and femle stimuli than would be expected by chance alone. Table VIII below contalns the number of "No Imagery" responses by sex of $\underline{S}$ and sex of stimuli. The only subject difference was in the imagery derling with the male stimulus. A significantly larger number of male $S$ s than female Ss indicated that they did not visualize a specific person when describing the male stimulus. There were no differences in stimulus conditions.

TABLE VIII

FREQUENCY OF NO IMAGERY BY SEX OF SUBJECT, STIMULUS, AND INS TRUMENT

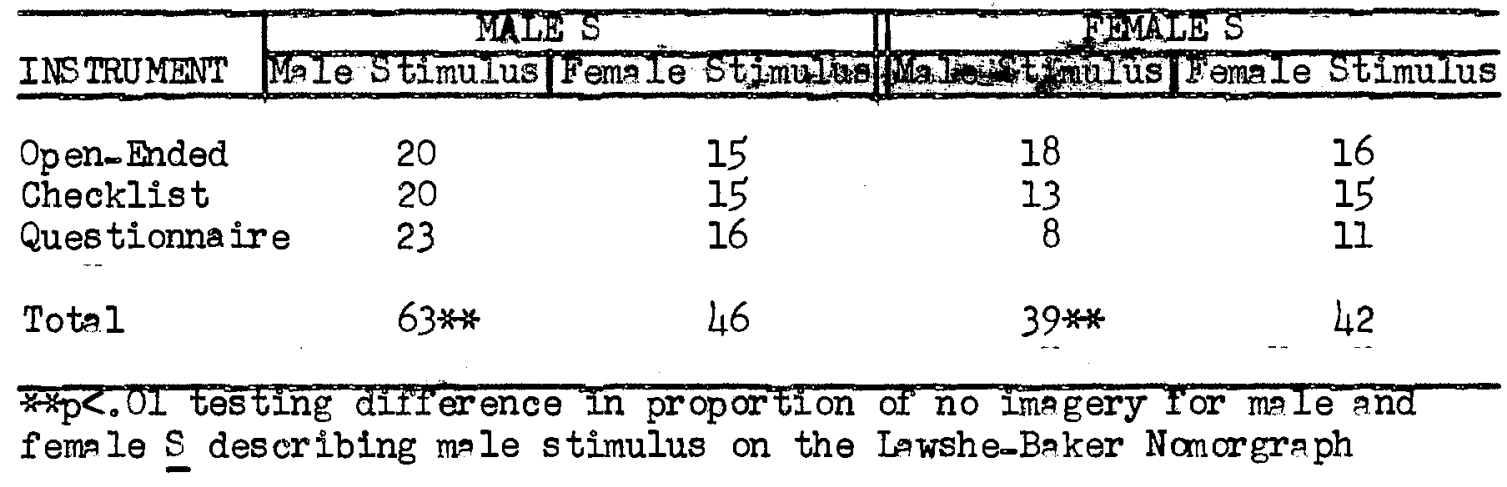


Trble IX reports the frequency of the persons being described by the Ss in all instrument conditions for male and female stimuli.

\section{TABLE IX}

\section{PERCENT OF SUBJECIS' RESPONSES RECARDING THE REIATIONSHIP OF THE IMAGERY PERSON}

\begin{tabular}{|c|c|c|c|c|c|c|}
\hline \multirow[b]{2}{*}{ REIATION } & \multicolumn{2}{|c|}{ CHECKEIST } & \multicolumn{2}{|c|}{ QUESTIONINIRE } & \multicolumn{2}{|c|}{ OPEN-EHDED } \\
\hline & $\begin{array}{l}\text { Male } \\
\text { Stimulus }\end{array}$ & $\begin{array}{l}\text { Femalo } \\
\text { S timulus }\end{array}$ & $\begin{array}{l}\text { Wole } \\
\text { Stimulus }\end{array}$ & $\begin{array}{l}\text { Hemele } \\
\text { Stimulus }\end{array}$ & $\begin{array}{l}\text { Male } \\
\text { Stimulus }\end{array}$ & $\begin{array}{l}\text { Female } \\
\text { Stimulus }\end{array}$ \\
\hline $\begin{array}{l}\text { Authority } \\
\text { Parental } \\
\text { Family } \\
\text { Spouse } \\
\text { Boyfriend } \\
\text { Girlfriend } \\
\text { Pëer } \\
\text { Mass Media } \\
\text { Other }\end{array}$ & $\begin{array}{c}5.8 \\
20.2 \\
8.4 \\
2.9 \\
23.2 \\
2.9 * \\
20.2 \\
7.2 \\
8.4\end{array}$ & $\begin{array}{r}6.1 \\
13.6 \\
6.1 \\
3.1 \\
0.0 \\
30.0 \\
25.8 \\
4.5 \\
10.6\end{array}$ & $\begin{array}{r}13.1 \\
14.7 \\
6.5 \\
11.4 \\
24.6 \\
0.0 \\
19.6 \\
1.6 \\
8.1\end{array}$ & $\begin{array}{r}4.6 \\
13.8 \\
6.1 \\
1.5 \\
0.0 \\
16.9 \\
40.0 \\
3.0 \\
13.8\end{array}$ & $\begin{array}{l}21.6 \\
16.6 \\
13.3 \\
5.0 \\
8.3 \\
1.6 * \\
16.6 \\
3.2 \\
13.3\end{array}$ & $\begin{array}{r}9.6 \\
12.9 \\
14.5 \\
1.6 \\
0.0 \\
16.1 \\
29.0 \\
1.6 \\
14.5\end{array}$ \\
\hline No Imagery & 37.5 & 34.0 & 35.2 & 31.0 & 43.0 & 35.0 \\
\hline
\end{tabular}

*It is possible that these Ss missed the stimulus cue, He.

\section{Validation of the Stereotypic Items}

The degree to which the stereotypic items on the Adjective Checklist and the Stereotype Questionnaire conveyed the information regardo ing the sex of the stimulus description was indicated in the responses of the Ss to questions \#6 and \#7 on the Validation Questionnaire. Trble X presents the percentage of "correct, "incorrect," and "not enough information" responses to the question of the sex of stimulus de- 
scription. In addition, the percentege of $\underline{S s}$ who reported that they were falrly confident (60-100 percent confidence) of their responses are reported in the same table. In comparing observed frequency of "correct," "incorrect," and "not enough information" responses with the expected frequency using Pearson's Ch1-Square, all description forms except the Adjective Checklist for femele description significantly departed from what would be expected by chance ( $p<.01)$.

TABLE X

PERCENT OF RESPONSES FOR QUES TION OF SEX OF STIMULUS DESCRIPTION WITH CONFIDENCE RATINGS OF 60\% TO $100 \%$

\begin{tabular}{|c|c|c|c|c|c|c|c|}
\hline INSTRUMENT & CORRECT & Conf: & Incorrect & Conf. & Not Inf. & Conf: & $x^{2}$ \\
\hline $\begin{array}{l}\text { Male Questionnaire } \\
\text { Femple Questionno ire } \\
\text { Male Checklist } \\
\text { Female Checklist }\end{array}$ & $\begin{array}{l}62.2 \\
\times \quad 57.7 \\
68.8 \\
51.1\end{array}$ & $\begin{array}{l}64 \\
58 \\
60 \\
65\end{array}$ & $\begin{array}{r}22.2 \\
26.6 \\
6.6 \\
28.8\end{array}$ & $\begin{array}{l}45 \\
75 \\
33 \\
46\end{array}$ & $\begin{array}{l}15.5 \\
15.5 \\
22.2 \\
20.2\end{array}$ & $\begin{array}{r}100 \\
71 \\
83 \\
77\end{array}$ & $\mid \begin{array}{l}17.23 * 6 * x \\
12.9 * 3 * \\
27.7 * * * 4 \\
6.9\end{array}$ \\
\hline
\end{tabular}

*xip. $01, x^{2}=9.21$, df $=2$ *xitp $<.001, x^{2}=13.8$, df $=2$

The validation dato were further examined through the use of an index of predictive association, lambda. This index shows the proportional reduction in the probability of error afforded by specifying values of variable "A。" A lambda value (range 0 to 1.0 ) is found by subtracting the probability of error with "A" values know from the 
probability of error with "A" unknown and then dividing by the probebility of "A" unknown. As Hays (1963) points out, it is possible for a statistical association to exist even though lambda is zero. In such a case, the variables are not independent, but the relationship is such that giving values of one variable does not cause a chenge in estimate of the other variable.

There no reduction in error in predicting the $\underline{S}^{\prime}$ responses to question \#6 when information was given as to what instrument was used; there wes only a 4 percent reduction in error of prediction when the S's response was used to predict which instrument was employed in the description. Thus, it was concluded that there was little assoclation between the instruments used, the Adjective Checklist and the Stereotype Questionnaire, and the Ss' responses of "correct," "Incorrect, and "not enough information" in the attribution of the sex of the stimulus description. However, in predieting the sex of the stimulus the $\underline{S}$ rated, Information concerning the $\underline{S}$ 's responses reduces error in prediction by 14 percent.

Also to be noted in Table $X$ is the Ss who incorrectly answered the question of sex of the stimulus report lower confidence in their answers (the female description on the Stereotype Questionnaire is an exception). Those Ss responding "not enough inf ormation" report higher confidence than the other two response categories. Responses to the other questions on the validation form cain be found in Table XI. 
TABLE XI

PERCENTAGE OF SUBJECIS RESPONDING TO EACH

ALTERNATIVE FOR VAIIDATION QUES TIONNAIRE

\begin{tabular}{|c|c|c|c|c|}
\hline \multirow[b]{2}{*}{ QUES TION } & \multicolumn{2}{|c|}{ QUES'IIONNAIRE } & \multicolumn{2}{|c|}{ CHECKKIHST } \\
\hline & $\begin{array}{c}\text { Male } \\
\text { Stimulus }\end{array}$ & $\begin{array}{c}\text { Femalo } \\
\text { StImalus } \\
\end{array}$ & $\begin{array}{c}\text { Mele } \\
\text { StImulue }\end{array}$ & $\begin{array}{c}\text { Femile } \\
\text { StImulus }\end{array}$ \\
\hline $\begin{array}{l}\text { Question \#2: } \\
15-19 \\
20-24 \\
25-30 \\
30-40 \\
40-\end{array}$ & $\begin{array}{r}28.8 \\
42.2 \\
17.7 \\
6.6 \\
4.4\end{array}$ & $\begin{array}{r}42.2 \\
37.7 \\
13.3 \\
6.6 \\
0.0\end{array}$ & $\begin{array}{r}17.7 \\
59.9 \\
17.7 \\
4.4 \\
0.0\end{array}$ & $\begin{array}{r}8.8 \\
66.6 \\
8.8 \\
8.8 \\
2.2\end{array}$ \\
\hline $\begin{array}{l}\text { Question \#3: } \\
0-20 \\
20-40 \\
40-60 \\
60-80 \\
80-100\end{array}$ & $\begin{array}{r}\text { Confidence } \\
\qquad \begin{array}{r}4.4 \\
8.8 \\
35.5 \\
42.2 \\
8.8\end{array}\end{array}$ & $\begin{array}{r}2.2 \\
17.1 \\
37.7 \\
33.3 \\
13.3\end{array}$ & $\begin{array}{r}8.8 \\
4.4 \\
31.1 \\
37.7 \\
17.7\end{array}$ & $\begin{array}{r}6.6 \\
8.8 \\
42.2 \\
35.5 \\
6.6\end{array}$ \\
\hline $\begin{array}{l}\text { Question \#4: } \\
\text { Not working } \\
\text { Student } \\
\text { Blue Collar } \\
\text { White Collar } \\
\text { Not Information }\end{array}$ & $\begin{array}{l}\text { Occupation } \\
\begin{aligned} & 2.2 \\
& \\
& 48.8 \\
& 0.0 \\
& \text { on } \quad 26.6 \\
& 17.7\end{aligned}\end{array}$ & $\begin{array}{r}0.0 \\
48.8 \\
6.6 \\
13.3 \\
28.8\end{array}$ & $\begin{array}{r}0.0 \\
46.6 \\
2.2 \\
13.3 \\
37.7\end{array}$ & $\begin{array}{r}4.4 \\
31.1 \\
11.1 \\
19.9 \\
33.3\end{array}$ \\
\hline $\begin{array}{l}\text { Question \#5: } \\
0-20 \\
20-40 \\
40-60 \\
60-80 \\
80-100\end{array}$ & 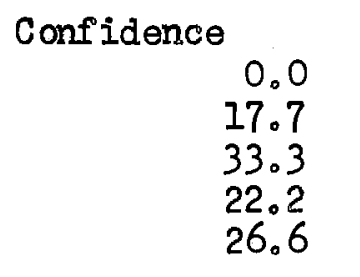 & $\begin{array}{r}6.6 \\
15.5 \\
24.4 \\
28.8 \\
24.4\end{array}$ & $\begin{array}{r}4.4 \\
2.2 \\
26.6 \\
37.7 \\
28.8\end{array}$ & $\begin{array}{r}6.6 \\
17.7 \\
28.8 \\
17.7 \\
26.6\end{array}$ \\
\hline $\begin{array}{l}\text { Quiestion \#6: } \mathrm{s} \\
\text { Male } \\
\text { Female } \\
\text { Not Inf ormation }\end{array}$ & $\begin{array}{l}62.2 \\
22.2 \\
15.5\end{array}$ & $\begin{array}{l}26.6 \\
57.7 \\
15.5\end{array}$ & $\begin{array}{r}68.8 \\
6.6 \\
22.2\end{array}$ & $\begin{array}{l}28.8 \\
51.1 \\
20.0\end{array}$ \\
\hline $\begin{array}{l}\text { Question \#7: } \\
0-20 \\
20-40 \\
40-60 \\
60-80 \\
80-100\end{array}$ & 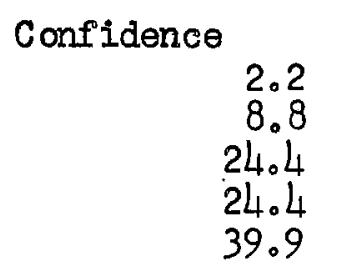 & $\begin{array}{r}2.2 \\
13.3 \\
19.9 \\
28.8 \\
35.5\end{array}$ & $\begin{array}{r}6.6 \\
6.6 \\
19.9 \\
31.1 \\
35.5\end{array}$ & $\begin{array}{l}4.4 \\
6.6 \\
26.6 \\
28.8 \\
33.3\end{array}$ \\
\hline
\end{tabular}


$X I$ (Continued)

\begin{tabular}{|c|c|c|c|c|}
\hline \multirow[b]{2}{*}{ QUES TION } & \multicolumn{2}{|c|}{ QUESTIONNAIRE } & \multicolumn{2}{|c|}{ CHECKIIST } \\
\hline & $\begin{array}{l}\text { Male } \\
\text { Stimulus }\end{array}$ & $\begin{array}{c}\text { Female } \\
\text { Stimulus }\end{array}$ & $\begin{array}{c}\text { Male } \\
\text { Stimulus }\end{array}$ & $\begin{array}{l}\text { Femalo } \\
\text { Stimulus }\end{array}$ \\
\hline $\begin{array}{l}\text { QuestIon \#8: } \\
\text { Desirable } \\
\text { Neither } \\
\text { Undesirable }\end{array}$ & $\begin{array}{r}\text { Desirability } \\
82.2 \\
11.1 \\
4.4\end{array}$ & $\begin{array}{r}55.57 \\
37.7 \\
6.6\end{array}$ & $\begin{array}{r}84.4 \\
8.8 \\
6.6\end{array}$ & $\begin{array}{c}{[93.37 *} \\
6.6 \\
0.0\end{array}$ \\
\hline $\begin{array}{l}\text { Question \#9: } \\
\text { Well-adjusted } \\
\text { Adequately } \\
\text { Poorly } \\
\text { Not Inf ormation }\end{array}$ & 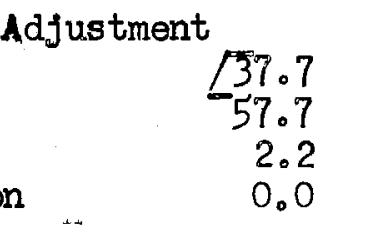 & $\begin{array}{r}33.37 \\
55.5 \\
8.8 \\
2.2\end{array}$ & $\begin{array}{r}575.5 \\
20.0 \\
0.0 \\
4.4\end{array}$ & $\begin{array}{l}84.47 * \\
8.8 \\
0.0 \\
6.6\end{array}$ \\
\hline $\begin{array}{l}\text { Questiôn \#10: } \\
\text { Yes Imagery } \\
\text { No Imagery }\end{array}$ & $\begin{array}{c}\text { Imagery } \\
\ldots\end{array}$ & $\begin{array}{l}53.3 \\
46.6\end{array}$ & $\begin{array}{l}55.5 \\
44.4\end{array}$ & $\begin{array}{l}55.5 \\
44.4\end{array}$ \\
\hline $\begin{array}{l}\text { Question \#ll: } \\
\text { Family } \\
\text { Boy/Girl Friend } \\
\text { Peer } \\
\text { Other } \\
\text { Not Applicable }\end{array}$ & $\begin{array}{ll}\text { Relation } & \\
& 11.9 \\
& 19.0 \\
16.6 & 16.6 \\
& 35.7\end{array}$ & $\begin{array}{l}7.1 \\
7.1 \\
19.0 \\
21.4 \\
45.2\end{array}$ & $\begin{array}{l}17.5 \\
12.5 \\
12.5 \\
17.5 \\
40.0\end{array}$ & $\begin{array}{l}13.9 \\
19.4 \\
19.4 \\
19.4 \\
27.7\end{array}$ \\
\hline
\end{tabular}

* Kor. Ol testing for differences in proportions by Lewshe-Baker Nomograph

Responses for the four forms. should be noted on questions eight and nine concerning desirability and adjustment, respectively. The female description on the Stereotype Questionnaire is significantly less desirable than the three other descriptions (test for difference in proportions by Lawshe-Baker Nomograph $n=45)$. On the adjustment dimension, both male and female descriptions of the Adjective Checklist are rated higher than the descriptions on the Stereotype Questionnaire. Again the test was by Lowshe-Baker Nomograph for differ- 
ences in proportions $(n-90)$. Of special interest is the difference on these two dimensions for the female descriptions on the different Instruments, the Checklist and the Stereotype Questionng1re. Again it appears that the Instruments do elicit different images, especielly in relation to female adult.

\section{Imagery}

It was hypothesized that in the velidation procedure the different instrument descriptions would ellcit different Images and thus different responses to the validation questions. A Chi-Square comparing the frequency of reported imagery and no imagery by instrument description showed no significant differences in imagery reported than would be expected by chance $\left(X^{2}=4.0\right.$, df $\left.=3\right)$. However, knowing whether Ss reported Imagery was found to reduce error in predlcting which instrument description the $S$ responded to by 14 percent as indicated by lambda.

In testing the reported frequency of Imagery on the validetion questionnaire for all descriptions combined, there was not a significantly larger number of $\underline{S}$ using imagery than would be expected by chance alone $\left(x^{2}=3.2, d f=1\right)$. However, when examining the frequency of reported imgery in conjunction with the $S^{\prime}$ ' response to the sex of the stimulus description, there emerge two relationships. Imagery was found to be related to: (I) correct attribution of sex of stimuli, and (2) greater confidence in that response. In regard to this first relationship, it can be seen in Table XII that significantly more correct responses are paired with visual imgery than correct response paired with no imagery ( $\mathrm{p} .01$ on Lawshe-Baker Nomograph for tests of 
difference between proportions, $\mathrm{n}=117$ ).

\section{TABLE XII}

PERCENT OF IMAGERY REPORTED BY RESPONSE ON ATTRIBUTION OF SEX OF THE

STIMULUS DESCRIPITON

\begin{tabular}{|c|c|c|c|c|}
\hline \multirow[b]{2}{*}{ INS TRUMENT } & \multicolumn{2}{|c|}{ CORRECI } & Incorrect & Not Emough Info. \\
\hline & Imagery & No & Imagery No & Imagery $1 \mathrm{No}$ \\
\hline $\begin{array}{l}\text { Ma le Questionnaire } \\
\text { Femole Questionnaire } \\
\text { Male Checklist } \\
\text { Female Checklist }\end{array}$ & $\begin{array}{l}42.2 \\
37.7 \\
31.1 \\
31.1\end{array}$ & $\begin{array}{l}19.9 \\
19.9 \\
35.5 \\
19.9\end{array}$ & $\begin{array}{rr}15.5 & 8.8 \\
11.1 & 15.5 \\
8.8 & 0.0 \\
15.5 & 13.3\end{array}$ & $\begin{array}{rr}4.4 & 8.8 \\
4.4 & 11.1 \\
17.7 & 6.6 \\
8.8 & 11.1\end{array}$ \\
\hline Total & $x \rightarrow 50.0$ & 40.07 & 56.044 .0 & $47.0 \quad 53.0$ \\
\hline
\end{tabular}

**op $<.01$ on Iawsge-Bakër Nomograph for testing differences between proportions. The total percentages are based on the number of $S$ responding in thet category not on $n=45$ as the instrument form percentages are.

With respect to the second relationship, Table XIII has information of imegery and response of sex of stimali broken down into levels of confidence in the SS' attribution of sex of stimuli. Across all Instrument descriptions and all responses on question \#6, looking only at 60 percent to 100 percent confidence ratings, a Chi-square test for frequency or reported imagery versus no imagery reverled no significant differences $\left(X^{2}=4.6\right.$, df $\left.=1\right)$. However, for those $S s$ who answered question $\# 6$ correctly and who had confidence ratings of 60 percent to 100 percent, there was significantly more imagery than would be ex- 


\section{TABLE XIII}

CONTINGENCY TABLE FOR RESPONSE, IMAGERY, AND

CONFIDENCE OF RESPONSE FOR SEX OF

STTMULUS DESCRIPIION

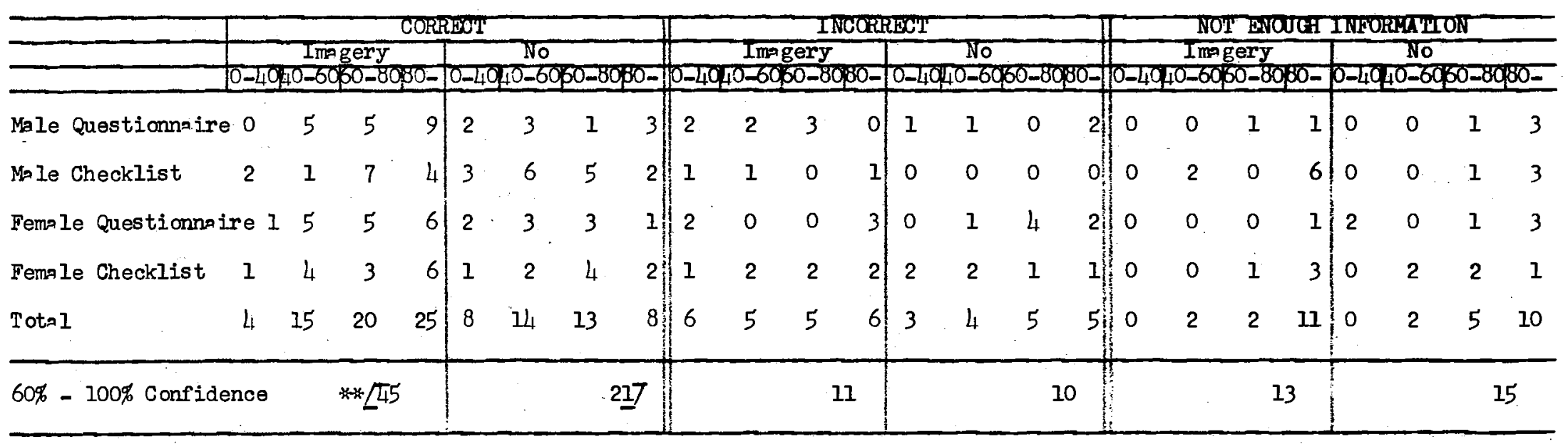

$* * 0.01, x^{2}=8.7$, df $=1$ 
pected by chance $\left(x^{2}=8.7\right.$, df $=1$ ). On the other hand, for $\underline{S}$ who answered correctly but reported low confidence (less than 60 percent), there was not a significantly larger number ueing imagery than would be expected by chance alone $\left(X^{2}=2.1\right.$, df $\left.=1\right)$.

In summary, from the date collected, it can be concluded that there are differences in trait attribution for female and male stimuli on the Adjective Checklist and the Stereotype Questionnaire, but no differences in the Open-Ended form. There is a difference in the content of stereotyplc items that emerged from the Adjective Checklist and Stereotype Questionnalre Instruments. This difference also can be seen from the responses on the validation questionnaire concerning percentage of correct attribution of sex of stimulus description, ratings of confidence, and ratings of adjustment and desirability. This difference of items will be discussed furtherente Imagery data in both the collection of stereotypic items and in the validation phase indicate that $S \mathrm{~s}$ when asked to adscribe an adult male and/or female, picture or visually imgine specific persons. This imagery appears to play some role in correct attribution of sex of stimulus and in greater confidence in that attribution.

It is thus concluded that the hypotheses of this research were supported. There are different traits attributed to males and females, different instruments elicit different stereotypic 1tens, and visual Imagery does play a role in sex stereotypes. 
CHAPTER IV

\section{DISCUSSION AND CONCLUSIONS}

This reseerch was designed to study methodological problems involved in sex stereotyping reserrch. It was not intended solely to gather information as to present sex stereotypes. Rather it was in. tended to examine the question of whether sex stereotypes can be measured by paper and pencil tasks. The main thrust of this research was to determine whether sex stereotypes are an artifact of the procedure and instrument used in collecting the stereotypic items, i.e. do different instruments and different procedures elicit different stereotypic items.

\section{Collection of Stereotypic Items}

Before this question of artifactness could be carefully examined there were other problems central to the procedure which had to be controlled. These were the stimuli used to elicit the responses and the manner in which the responses were collected. In previous literature these have been the greatest source of demand characteristics. The subtle stimulus cues of he and she may elicit very different stereotypic items than stimuli such as "adult men" or "most women." Using two forms or copies of an instrument for each $\underline{S}$ responses may greatly reduce the contrast of the two stimuli. These problems were arbitrarily controlled rather than manipulated as variables. However, 
the subtle stimuli and the two forms provide what appears to be a less obtrusive attempt of asking college students how they expect men and women to differ. This less obtrusive approach may allow the Ss more of an opportunity to respond with items that are more salient for him as an individual.

It may be these differences in procedure which resulted in the discrepancy between the findings of this research and that of some previously cited studies. For an exaraple, the Stereotype Questionnaire revealed only ten itens as significant differentiators as compared with Rosenkrantz's 53 items. For the most part, there is an absence of negative items assigned to male and female, especially the female, which is inconsistent with other literature.

While it first appeared that differences in trait attribution to males and females on the Open- Ended form would be more salient for the S than on the other more structured forms, no significant differences emerged for male and female stimuli, and very little consensus was reached among the $\mathrm{Ss}$. In the situation where the cognitive process of stereotyping should be most evident it was not. The less obtrusive cues discussed above may be the reason for the absence of stereotypic items. However, examining the zmscores for the items masculine and feminine on the Checklist and Stereotype Questionnaire (items \#86, \#147 in Appendix $G$ and items \#79 and \#80 in Appendix H), it is clear that $\mathrm{Ss}$ in the overall sample responded appropriately to the cues he and she. Thus it did not appear to be a problem of missing the cues of sex of stimuli but an actual difference in perception.

Sherif and Sherif (1969) stated 12 basis propositions or principles in the study of social behavior, two of which are directly 
applicable to what is being discussed. The first is that the more unstructured the stimulus situation, the greater the contribution of internal factors. In this research the internal factors would be the S's own stereotypes. The second proposition is that the more unstructured the stimulus situation, the greater the effectiveness of external social influences that offer alternatives to the psychological patterning. It is proposed that the structure and content of an instrument provides this external influence in the collection of stereotypes.

\section{Validation of the Stereotypic Items}

In the validation data there are throe important points that provide further support of the view of stereotypes as artifacts of the instruments used. First, the differences in response to the question as to the sex of the stimulus description showed that more Ss felt the Checklist provided less information concerning the sex of the stimulus than the Stereotype Questionnoire. There does appear to be a greater influence or difference in responses to the question by the sex of the stimulus description than by instrument. Even so, the Stereotype Questionnaire exhibits less difference between male and female description across all responses than does the Adjective Checklist.

Second, is the information received by the $S s$ from the instruments in response to questions \#8 and \#9 on desirability and adjustment. Clearly, the two instruments reflect differential information as to these two dimensions especially in regard to the female stimulus which was seen more desirable and better adjusted on the Adjective Checklist than the Stereotype Questionnaire.

Third is the use of imagery. As stated in Chapter III, there is 
a reduction in the amount of error made in predicting which instrument a S used if it is known whether the $\underline{S}$ reported Imagery. It thus appears that the different instruments elicit a different amount of imagery by Ss.

From the validation data, it can be further concluded that stereotypic descriptions and Ss' responses to those descriptions are very much related to how those descriptions were initially measured, i。 $\theta_{0}$ stereotypes are artifacts of instruments and procedure used to obtain the items. This is not to deny the existence of sex stereotypes. It is to suggest, however, that the most important aspects of stereotypes have gone unnoticed because social scientists have been too closely tied to their instruments and procedure. Questions of development and function of stereotypes are still unanswered. By limiting the study of stereotypes to paper and pencil tasks it is possible that these questions will remaln unanswered.

\section{Visua 1 Imagery}

The findings of this research relating to visual imagery offer a beginning point for more profitable gvenues of exploration in the process and function of sex stereotypes. The role of imagery in stereotyping has not been examined before now. What this research has shown is that imagery is present while Ss are responding to the stimulus 8 is significantly less when males are describing males; is significantly more likely in Ss who thribute correctly the sex of the stimulus description; and is related to greater confidence in correct attribus tion of sex of stimulus.

As stated early in the paper, stereotypes are considered as cate. 
gorlcel process in which groups of people are placed and associeted with certain physical traits and personality characteristics. Same of the assoclated traits mey be valld or true reflection of existing group differences or they may be unjustified generalizations. In elther case, cognitively the stereotype serves the function of storage of patterns of general traits associated with that group (Sherriff and Jarrett, 1953). It may be that the role visual imagery plays is a releasing of this information from atorage for the perceiver or $S$ to once again process the information or revlew it in order to make a judgment or response to the stimulus object. If this is the case, it would be expected that $S s$ who report visual Imagery would have more correct responses with greeter confldence.

The Iiterature of visual imagery indicates that people who report visual imagery are more accurate in recall of a task as long as the image persists and that people who visualize are more confident in their recall of a picture they have seen (Neisser, 1967). These find. ings support the possible role that imagery performed in this validas tion of the sex stereotypes.

\section{Implications of the Reserrch}

There are two major implicetions resulting from the findings of this research. First, it has been established that sex stereotypes are an artifact of the experimentel situation, $i_{0} e$ o the instrument and procedure. In order to study sex stereotypes realistically, it may be necessary to go to more naturalistic observations. Individual testing with detailed debriefing may provide much needed information concerno ing the process of sex stereotyping for the individual and its function. 
What needs to be done is a reevaluation of sex stereotyping research and its techniques. It is suggested that a move away from collection of stereotypes of the population is called for with a move toward the study of process and function for the individual.

The second implication has to do with visual imagery. As viewed in a clinical setting, it is suggested that imagery may serve an importent function for the individual in the processing and incorporating of theropeutic material. If the confidence in responding, previously noted, is found for those who experience imagery in the therapeutic setting, it may well have much implication for future developments in therapeutic techniques. 


\section{CHAPTER V}

\section{SUMMARY}

This research was designed to examine methodological problems of sex stereotyping research. Three instruments used in pest research served as instruments: Gough and Heiburn (1965) Adjective Checklist, Stereotype Questionnaire (Rosenkrantz et al., 1968) and an open-ended form. Sequence of stimulus presentation and sex of subject were included as variables. When item analysis by Lawshe-Baker Nomograph reverled no significant sex or sequence effects, the data was combined for instruments producing 88 subjects per instrument. There were $?$ total of $132 \mathrm{male}$ and 132 female undergraduates who served as subjects in the collection phase.

In the validation phase, those items which had been found to differentiate moles and females on the Adjective Checklist and those items used by 40 percent of the sample to describe either or both sexes were included on the validation questionnaire. Mean scores for the Stereotype Questionnaire for males and females were marked on the validation form for the Stereotype Questionnaire. A sample of 180 subjects were tested in this phase.

Three major hypotheses were tested and supported at the .01 level. First, there was a difference in trait attribution to male and females on the Adjective Checklist, and the Stereotype Questionnoire but not on the Open. Ended form. Second, there was a difference in the descrip. 
tion of the stimulus depending upon which of the two instruments was used. This was supported by the 1tems which emerged as stereotypic and from the responses on the validation questionneire for the different instruments. Third, when asked to describe a male or femple adult, subjects did picture specific persons while they were responding to the stimulus. Thls was found both in the collection and the validation phases. Visual imagery was found to be related to accuracy in attribution of sex of stimulus description and to confidence in the response. It was concluded that paper and pencil test will yield stereotyplc items which are, to some extent, artifacts of the instrument used. Further investigation is called for on the role of visual imagery in stereotyping. 
Bower, G. H. "Analysis of a Mnemonic Device." American Scientist, $1970,58,496-510$ 。

Brigham, J. C. "Ethnic Stereotypes 。" Psychological Bulletin, 1971, $76,15-38$.

Broverman, I. Ko, D。 Mo Broverman, F。 E。 Clarkson, P.S. Rozenkrantz, and S.R. Vogel. "S ex Roles Stereotypes and Clinicel Judgments of Mental Health. Journal of Consulting and Clinical Psychology, 1970, 34, I-7.

Brown, R. Words and Things. Glencoe, Ill。: The Free Press, 1958.

Campbell, D. "Stereotypes and Perception of Group Differences." American Psychologist, 1967, 22, 817-829.

Clarkson, E. K., S. R。 Vogel, I. Ko Broverman, D。 M. Broverman, and P. S. Rosenkrantz. "Family Size and Sex-role Stereotypes." Science, 1971, 167, 390-392.

Diamond, S. "Sex Stereotypes and Acceptance of Sex Role." Journal of Psychology, 1955, 39, 385-388.

Downie, No and R. Heath. Basic Statistical Methods. New York: Harper and Row, 1965.

Ehrlich, H。J. and J。 W。 Rinehart. "A Brief Report on the Methodology of Stereotyping Research." Socigl Forces, 1965, 43, 564-575.

Fernberger, S. Wo "Persistence of Stereotypes Concerning Sex Differ. ences." Journal of Abnormal and Social Psychology, 1948, 43, $97-101$.

Gough, Ho Go and A. B. Heilburn。 Adjective Checklist Manual。 Palo Alto: Consulting Psychologists Press, 1965.

Hays, Wo Statistics. New York: Holt, Rinehart and Winston, 1963.

Jenkin, No and $\mathrm{K}$. Vroegh. "Contemporary Concepts of Masculinity and Femininity。" Psychological Reports, 1969, 25, 679-697.

Katz, $D_{0}$ and $K$. W。 Braly. "Racial Stëreotypes of One Hundred College Students." Journal of Abnormal and Social Psychology, 1933, 28, 282-290。 
Lippmann, W. Public Opinion. New York: Harcourt, Brace, 1922.

Lunneborg,"P. "Stereotypic Aspect in Masculinity-Femininity." Journa I of Consulting and Clinical Psychology, 1970, 34, 113-118.

McKee, J. Do and A. C. Sherriff. "The Differential Evaluation of Ma les and Females." Journel of Personality, 1957, 25, 356-371.

- "Men's and Women's Beliefs, Ideals, and Self-concepts." American Journal of Sociology, $1959,64,356-363$.

Neisser, U. Cognitive Psychology. New York: Appleton-Century Crofts, 1967.

Ome, M. "On the Social Psychology of the Psychological Experiment: With Particular Reference to Demand Characteristics and Their Implications" (Paper read at American Psychological Association, New York, 1961)。

Rand, L。 Masculinity of Femininity? Differentiating Career-Oriented and Homemakingaoriented College Freshmen Women." Journal of Counseling Psychology, 1968, 15; $444-450$.

Rosenkrantz, P.S., S. Vogel, H. Bee, I. K. Broverman, D. M. Broverman. "S ex-Role Stereotypes and Self Cơncepts in College Students." Journal of Consulting and Clinical Psychology, 1968, 32, 287-295.

Rosentha 1, R. "On the Social Psychology of the Psychological Experiment: With Particular Reference to Experimenter Bias." (Paper read at American Psychological Association, New York, 1961).

Sherif, Mo and C. Sherif. Social Psychology. New York: Harper and Row, 1969.

Sherriff, A。C. and R。F. Jarrett. "Sex Differences in Attitudes About Sex Differences." Journal of Psychology, 1953, 35, 161-168.

Sherriff, A。C. and Jo D。McKee. "Qualitative Aspects of Beliefs About Men and Women." Journal of Personality, 1957, 25, 451-464.

Vinacke, Wo E。 "Explorgtions in the Dynamic Process of Stereotyping。" Journal of Social Psychology, 1956, 43, 105-132。 
APPENDICES 
APP ENIIX A

ADJECTIVE CHECKIIST

$-55-$ 
PLEASE CIRCLE EACH ITEM THAT YOU FEEL DESCRIBES THE STIMULUS PERSON.

\begin{tabular}{|c|c|c|c|}
\hline $\begin{array}{l}\text { 1. absent-minded } \\
\text { 2. active } \\
\text { 3. adaptable } \\
\text { 4. adventur ous } \\
\text { 5. affected } \\
\text { 6. affectionate } \\
\text { 7. aggressive } \\
\text { 8. alert } \\
\text { 9. aloof } \\
\text { 0. ambitous } \\
\text { 1. anxious } \\
\text { 2. apathetic } \\
\text { 3. appreciative } \\
\text { 4. argumentative } \\
\text { 5. arrogant } \\
\text { 6. artistic } \\
\text { 7. assertive } \\
\text { 8. attractive } \\
\text { 9. autocratic } \\
\text { 0. awkward } \\
\text { 1. bitter } \\
\text { 2. blustery } \\
\text { 3. boastful } \\
\text { 4. bossy } \\
\text { 5. calm } \\
\text { 6. capable } \\
\text { 7. careless } \\
\text { 8. cautious } \\
\text { 9. changeable } \\
\text { 0. charming } \\
\text { 1. cheerful } \\
\text { 2. civilized } \\
\text { 3. clear-thinking } \\
\text { 4. clever } \\
\text { 5. conrse } \\
\text { 6. cold } \\
\text { 7. commonplace } \\
\text { 8. complicated } \\
\text { 9. complaining } \\
\text { 0. conceited } \\
\text { 1. confident } \\
\text { 2. confused } \\
\text { 3. conscientious } \\
\text { 4. conservative } \\
\text { 5. considerate } \\
\text { 6. contented } \\
\text { 7. conventiongl } \\
\text { 8. cool } \\
\text { 9. cooperative } \\
\text { 0. courggeous } \\
\text { 9. }\end{array}$ & 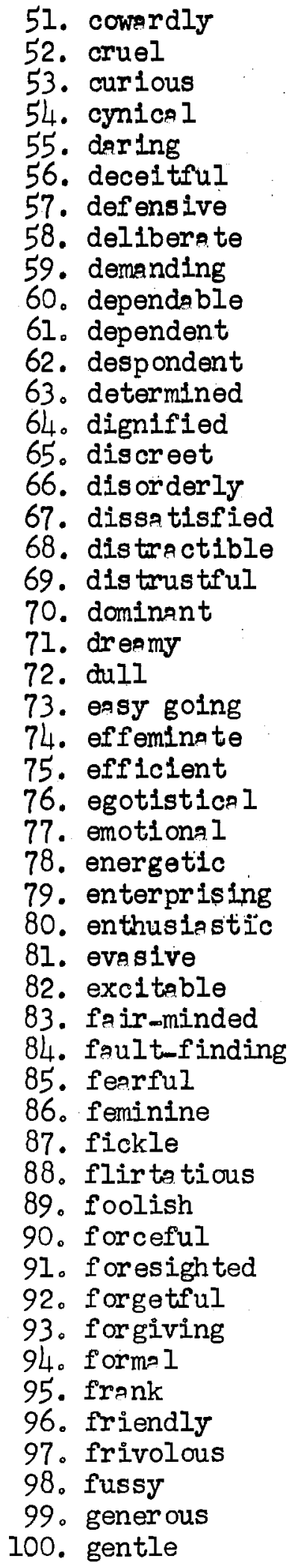 & $\begin{array}{l}101 . \\
102 . \\
103 . \\
104 . \\
105 . \\
106 . \\
107 . \\
108 . \\
109 . \\
110 . \\
111 . \\
112 . \\
113 . \\
114 . \\
115 . \\
116 . \\
117 . \\
118 . \\
119 . \\
120 . \\
121 . \\
122 . \\
123 . \\
124 . \\
125 . \\
126 . \\
127 . \\
128 . \\
129 . \\
130 . \\
131 . \\
132 . \\
133 . \\
134 . \\
135 . \\
136 . \\
137 . \\
138 . \\
139 . \\
140 . \\
141 . \\
142 . \\
143 . \\
144 . \\
145 . \\
146 . \\
147 . \\
148 . \\
149 . \\
150 .\end{array}$ & 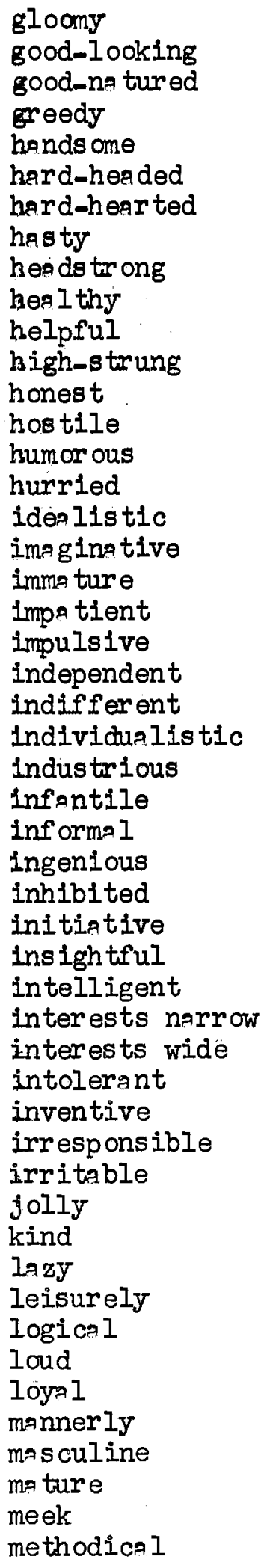 \\
\hline
\end{tabular}


151. mild

152. mischievous

153. moderate

154. modest

155. moody

156. nagging

157. natural

158. nervous

159. noisy

160. obliging

161. obnoxious

162. opini ona ted

163. opportunistic

164. optimistic

165. organized

166. originaI

167. outgoing

168. outspoken

169. painstoking

170. patient

171. perceable

172. peculiar

173. persevering

174. persistent

175. pessimistic

176. planful

177. pleasant

178. pleasure-seeking

179. poised

180. polished

181. practicel

182. praising

183. preclse

184. prejudiced

185. preoccupied

186. progressive

187. prudish

188. quarrels ome

189. queer

190. quick

191. quiet

192. quitting

193. rationa I

194. rattlebrained

195. realis tic

196. reas onable

197. rebellious

198. reckless

199. reflective

200. reloxed
201. reliable

202. resentful

203. reserved

204. resourceful

205. responsible

206. restless

207. retiring

208. rigid

209. robust

210. rude

211. sarcastic

212. self-center ed

213. self-confident

214. self-controlled

215. self-denying

216. self-pitying

217. self-punishing

218. self-seeking

219. selfish

220. sensitive

221. sentimental

222. serious

223. severe

224. sexy

225. shallow

226. sharp-witted

227. shiftless

228. show-off

229. skmewd -..

230. shy

231. silent

232. simple

233. sincere

234. slipshod

235. slow

236. sly

237. smug

238. snobbish

239. sociable

240. softmeerted

24I. sophisticated

242. spendthrift

243. spineless

244. sp on toneous

245. spunky

246. stable

247. steady

248. stern

249. stingy

250. stolid
251. strong

252. stabborn

253. submissive

254. suggestible

255. sulky

256. superstitious

257. suspicious

258. sympe thetic

259. tactful

260. tactess

261. talkative

262. temperamental

263. tense

264. thankless

265. th or ough

266. thoughtfuI

267. thrifty

268. timid

269. tolerant

270. touchy

271. tough

272. trusting

273. unaffected

274. unambitious

275. unassuming

276. unconventional

277. undependable

278. understanding

279. unemotional

280. unexcitable

281. unfriendly

282. uninhibited

283. unintelligent

284. unkind

285. unrea Iistic

286. unscrupulous

287. unselfish

288. unstable

289. vindicative

290. versatile

291. warm

292. wary

293. weak

294. whiny

295. wholes ome

296. wise

297. withdrawn

298. witty

299. worrying

300. zany 
APP ENBIX B

STEREDTYPE QUESTIONNAIRE 
ON EACH SCALE, PLEASE PUT A SLASH (/) ACCORDING TO WHAT YOU THINK THE STIMULUS PERSON IS LIKE.

For example:

strong dislike for

color red

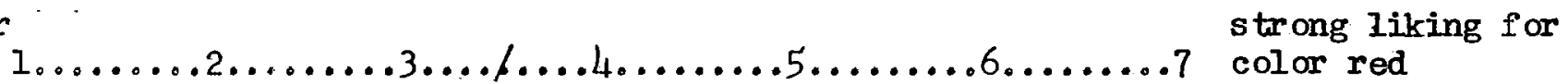

ON THE FOLLOWING PAGES ARE A NUMBER OF SCALES IIKE THE ONE ABOVE. YOU MAY PUT YOUR SLASH ANYWHERE ON THE SCALE, NOT JUST AT THE NUMBERS. PLEASE BE SURE TO MARK EVERY I TEM.

1. Not at all aggressive $1 \ldots \ldots .2 \ldots \ldots . \ldots \ldots 4 \ldots \ldots .6 \ldots \ldots 6 \ldots \ldots 7$ Very aggressive*

2. Very irrational

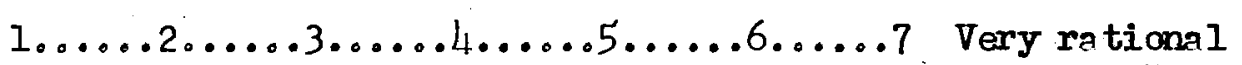

3. Very practical

$1 \ldots \ldots . \ldots \ldots 3 \ldots \ldots .4 \ldots \ldots 5 \ldots \ldots 6 \ldots \ldots 7$ Very impractical

4. Not at all independent $1 \ldots \ldots . \ldots \ldots 3 \ldots \ldots 4 \ldots \ldots 5 \ldots \ldots 6 \ldots \ldots 7$ Very independent

5. Not at all consistent $1 \ldots \ldots 2 \ldots \ldots 3 \ldots \ldots 4 \ldots \ldots 5 \ldots \ldots 6 \ldots \ldots 7$ Very consistent

6. Very emotional $\quad 1 \ldots \ldots 2 \ldots \ldots 3 \ldots \ldots 4 \ldots \ldots 5 \ldots \ldots 6 \ldots \ldots 7$ Not at all emotional

7. Very realistic $\quad 1 \ldots \ldots . \ldots \ldots 3 \ldots \ldots 4 \ldots \ldots . \ldots \ldots 6 \ldots \ldots 7$ Not at all realistic

8. Not at all idealistic $1 \ldots \ldots . \ldots \ldots 3 \ldots \ldots 4 \ldots \ldots . \ldots \ldots 6 \ldots \ldots 7$ Very idealistic 9. Does not hide emotions
at all
a $\ldots \ldots . \ldots \ldots 3 \ldots \ldots 4 \ldots \ldots 5 \ldots \ldots 6 \ldots \ldots 7$ emotions

10. Very subjective $\quad 1 \ldots \ldots . \ldots \ldots 3 \ldots \ldots 4 \ldots \ldots 5 \ldots \ldots 6 \ldots \ldots 7$ Very objective 
11. Mainly interested in details

12. Always thinks before acting

13. Not at all easily influenced

14. Not at all talkative

15. Very grateful

16. Doesn't mind at all when things are not clear

17. Very dominant $1 \ldots \ldots . . \ldots . . \ldots 4 \ldots \ldots . \ldots \ldots 6 \ldots \ldots$

18. Dislikes math and science very much

$$
\text { I. . }
$$

19. Not at all reckless

$1 \ldots \ldots 2 \ldots \ldots 3 \ldots \ldots 4 \ldots \ldots 5 \ldots \ldots 6 \ldots \ldots 7$

20. Not at all excitable in a major crisis

$$
1
$$

21. Not at all excitable in a minor crisis $1 \ldots \ldots . \ldots . . . \ldots 4 \ldots . \ldots 5 \ldots \ldots 6 \ldots \ldots$

22. Not at all strict $1 \ldots \ldots 2 \ldots \ldots . \ldots \ldots 4 \ldots \ldots 5, \ldots \ldots 6 \ldots \ldots$

23. Very weak personality

24. Very active
Mainly interested in generalities

$1 \ldots \ldots .2 \ldots \ldots 3 \ldots \ldots 4 \ldots \ldots .5 \ldots \ldots 6 \ldots \ldots 7$ Never thinks before acting

$1 \ldots \ldots .2 \ldots . .3 \ldots .4 \ldots .6 . \ldots .6 . \ldots 7$ Very easily influenced

$1 \ldots \ldots . \ldots \ldots 3 \ldots \ldots 4 \ldots \ldots . \ldots \ldots .6 \ldots . .6$ Very talkative

$1 \ldots \ldots . \ldots \ldots 3 \ldots \ldots 4 \ldots \ldots 5 \ldots \ldots 6 \ldots . . .6$ Very ungrateful

Minds very much when things are not clear

Very submissive

Likes math and science very much

\section{Very reckless}

Very excitable in a major crisis

Very excitable in a minor crisis

7 Very strict

$\ldots \ldots . \ldots . .3 \ldots \ldots 4 \ldots \ldots 5 \ldots \ldots 6 \ldots \ldots 7$ Very strong personality

$1 \ldots \ldots 2 \ldots \ldots 3 . \ldots 4 \ldots \ldots 5 \ldots \ldots 6 \ldots \ldots 7$ Very passive 
25. Not at all able to devote self

completely to others $1 \ldots \ldots 2 \ldots \ldots . \ldots .4 \ldots \ldots 5 \ldots \ldots 6 \ldots \ldots 7$ to others

26. Very blunt

$1 \ldots \ldots 2 \ldots \ldots . \ldots .4 . \ldots .5 \ldots \ldots 6 \ldots \ldots 7$ Very tactful

27. Very gentle

$1 \ldots \ldots . \ldots \ldots 3 \ldots \ldots 4 \ldots \ldots 5 \ldots \ldots 6 \ldots . .6$ Very rough

28. Very helpful to others $1 \ldots \ldots .2 \ldots \ldots 3 \ldots \ldots 4 \ldots \ldots 5 \ldots \ldots 6 \ldots \ldots 7$ Not at all helpful to others

29. Not at all competitive $1 \ldots \ldots .2 \ldots . \ldots \ldots 4 \ldots \ldots . \ldots \ldots 6 \ldots \ldots 7$ Very competitive

30. Very logical

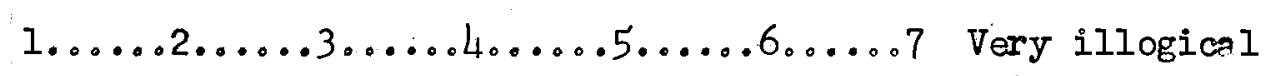

31. Not at all competent

$1 \ldots \ldots .2 \ldots \ldots 3 \ldots \ldots 4 \ldots \ldots 5 \ldots \ldots 6 \ldots \ldots 7$ Very competent

32. Very worldly

$1 \ldots \ldots 2 \ldots \ldots 3 \ldots \ldots 4 \ldots \ldots 5 \ldots \ldots 6 \ldots \ldots 7$ Very home oriented

33. Not at all skilled in business

$1 \ldots \ldots 2 \ldots \ldots 3 \ldots \ldots 4 \ldots \ldots 5 \ldots \ldots 6 \ldots \ldots 7$ Very skilled in business

34. Very direct

$1 \ldots \ldots .2 \ldots . .3 \ldots .4 \ldots \ldots 5 \ldots \ldots 6 \ldots . .6$ Very sneaky

35. Known the ways of the world

$1 \ldots \ldots 2 \ldots \ldots 3 \ldots \ldots 4 \ldots \ldots 5 \ldots \ldots 6 \ldots \ldots 7$ world

36. Not at all kind

$1 \ldots \ldots 2 \ldots \ldots 3 \ldots \ldots 4 \ldots \ldots . \ldots \ldots 6 \ldots \ldots 7$ very kind

37. Not at 211 willing to accept change

$1 \ldots \ldots . \ldots . . . . . .4, \ldots .5$

Very, willing to accept

change

38. Feelings not easily hurt

$1 \ldots \ldots 2 \ldots \ldots 3 \ldots \ldots 4 \ldots \ldots 5 \ldots \ldots 6 \ldots \ldots 7$ Feelings easily hurt

39. Not at all adventurous $1 \ldots \ldots . \ldots \ldots 3 \ldots \ldots . \ldots \ldots . \ldots .6 . \ldots .7$ Very adventurous 
40. Very awere of the feelings

Not at all aware of the of others

$1 \ldots \ldots . . \ldots . . \ldots .4 . \ldots .5 \ldots \ldots 6 \ldots \ldots 7$ feelings of others

41. Not at all religious

$1 \ldots \ldots . \ldots . .3 \ldots \ldots 4 \ldots \ldots . \ldots \ldots 6 \ldots \ldots 7$ Very religious

42. Not at all intelligent $1 \ldots \ldots . \ldots \ldots . \ldots . \ldots 4 \ldots \ldots 5 \ldots \ldots 6 \ldots \ldots 7$ Very intelligent

43. Not at all interested in own appearance

$1 \ldots \ldots .2 \ldots \ldots 3 \ldots \ldots .4 \ldots \ldots 5 \ldots \ldots 6, \ldots \ldots 7$ Very interested in own

44. Can make decisions easily

$1 \ldots .0 .2 \ldots \ldots 3 \ldots \ldots 4 \ldots \ldots .5 \ldots \ldots 6 \ldots \ldots 7$ decisions

45. Gives up very easily $1 \ldots \ldots . . \ldots .63 \ldots \ldots .4 \ldots \ldots 5 \ldots \ldots 6 \ldots \ldots 7$ Never gives up easily

46. Very shy

$1 . \ldots \ldots 2 \ldots \ldots . \ldots . \ldots 4 \ldots \ldots 5 \ldots \ldots 6 \ldots . .67$ Very outgoing

47. Always does things without being told

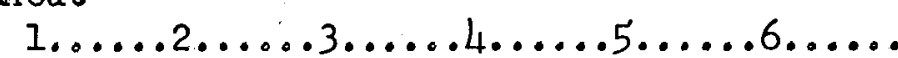

Never does things without being told

48. Never cries

$1 \ldots \ldots .2 . \ldots . . \ldots .4 \ldots \ldots 5 \ldots \ldots 6 \ldots \ldots$

Cries very easily

49. Almost never acts as $\%$ leader

$1 \ldots \ldots . \ldots \ldots 3 \ldots \ldots 4 \ldots \ldots .5 \ldots \ldots 6 \ldots \ldots 7$ leader

50. Never worried

$1 \ldots \ldots .2 \ldots \ldots 3 . \ldots .4 \ldots \ldots 5 \ldots \ldots 6 \ldots \ldots 7$ Always worried

51. Very neat in habits

$1 \ldots \ldots 2 \ldots \ldots 3 \ldots . .4 \ldots \ldots 5 \ldots . .6 . .67$ very sloppy in habits

52. Very quiet

$1 \ldots \ldots . \ldots \ldots 3 \ldots \ldots 4 \ldots \ldots . \ldots \ldots . \ldots . .6$ Very loud

53. Not at all intellectual $1 \ldots \ldots 2 \ldots \ldots . \ldots \ldots 4 \ldots \ldots 5 \ldots \ldots 6 \ldots \ldots 7$ Very intellectual

54. Very careful

$1 \ldots \ldots 2 . \ldots . . \ldots 4 \ldots \ldots . \ldots .6 . \ldots 7$ Very careless 
55. Not at all selfconfident

$1 . \ldots .2 \ldots \ldots . \ldots \ldots 4 \ldots \ldots . \ldots . \ldots 6 \ldots \ldots 7$ Very self-confident

56. Feels very superior

$1 \ldots . . .2 \ldots .3 \ldots \ldots 4 \ldots \ldots 5 \ldots \ldots 6 \ldots . .6$ Feels very inferior

57. Always sees self as running the show

$$
1 \ldots \ldots . . \ldots . . \ldots \ldots 4 \ldots \ldots . \ldots \ldots . \ldots .67
$$

\section{Never sees self as running} the show

58. Not at all uncomfortable about being aggressive $1 \ldots \ldots . \ldots \ldots 3 \ldots \ldots 4 \ldots \ldots . \ldots . \ldots 6 \ldots \ldots 7$ being aggressive

59. Very good sense of humor

$$
1 \ldots \ldots .2 \ldots \ldots . \ldots \ldots .4 \ldots \ldots 5 \ldots \ldots .6 \ldots .67 \text { Very poor sense of humor }
$$

60. Not at all understanding of others

61. Very werm in relations with others others

62. Doesn't care about being in a group

63. Very little need for security security

64. Not at all ambitious

$1 \ldots \ldots . \ldots \ldots 3 \ldots \ldots 4 \ldots \ldots . \ldots .66 \ldots .$.

\section{Very ambitious}

65. Very rariely takes extreme positions positions

66. Able to separate feelings from ideas 
67. Not at all dependent $1 \ldots \ldots 2 \ldots \ldots . \ldots \ldots 4 \ldots \ldots 5 \ldots \ldots 6 \ldots \ldots 7$ Very dependent

68. Does not enjoy art and literature at all

$1 \ldots \ldots . \ldots \ldots . \ldots \ldots 4 \ldots \ldots .6 \ldots \ldots 6 \ldots \ldots 7$ Enjoys ar

69. Seeks out new experiences

$1 \ldots \ldots 2 \ldots \ldots 3 \ldots \ldots 4 \ldots \ldots . \ldots .6 . \ldots .67$ Avoids new experiences

70. Not at all restless

$1 \ldots \ldots 2 \ldots \ldots 3 \ldots \ldots .4 \ldots \ldots 5 \ldots \ldots 6 \ldots \ldots 7$ Very restless

71. Very uncomfortable when people express emotions

$1 \ldots \ldots . . \ldots 3 \ldots \ldots 4 \ldots \ldots 5$. . . . .

$5 \ldots \ldots 6 \ldots . . . .6$

Not at all uncomfortable when people express emotions

72. Fasily expresses tender feelings

$$
1 .
$$$$
1 \ldots \ldots .2 \ldots \ldots 3 \ldots \ldots .4 \ldots \ldots .5 \ldots \ldots 6 \ldots \ldots 7
$$

Does not express tender feelings easily

73. Very conceited about appearance

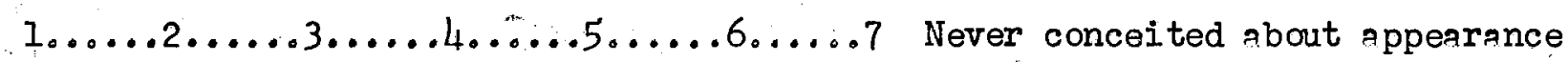

74. Retiring

$1 \ldots \ldots . \ldots \ldots 3 \ldots \ldots 4 \ldots \ldots . \ldots \ldots 6 \ldots . .6$ Forward

75. Thinks men are superior to women

$$
1 .
$$
Does not think men are superior

76. Very sociable $1 \ldots . .2 \ldots \ldots 3 \ldots \ldots 4 \ldots . .5 \ldots .6 . \ldots .7$ Not at all sociable

77. Very affectionate $1 \ldots \ldots . \ldots \ldots 3 \ldots \ldots . \ldots 4 \ldots . \ldots .6 . \ldots 7$ Not at all affectionate

78. Very conventional $1 \ldots \ldots 2 \ldots \ldots . \ldots . \ldots 4 \ldots \ldots 5 \ldots \ldots 6 \ldots \ldots 7$ Not at all conventional

79. Very masculine $1 \ldots \ldots 2 \ldots \ldots 3 \ldots \ldots 4 \ldots \ldots 5 \ldots \ldots 6 \ldots .6$ Not at all masculine

80. Very feminine $1 \ldots \ldots . \ldots \ldots 3 \ldots \ldots 4 \ldots \ldots 5 \ldots \ldots 6 \ldots . .6$ Not at all feminine 
81. Very assertive

$1 \ldots \ldots .2 \ldots \ldots 3 \ldots \ldots 4 \ldots \ldots . \ldots \ldots 6 \ldots \ldots 7$ Not at all assertive

82. Very impulsive

$1 \ldots \ldots . \ldots . .3 \ldots . .4 \ldots .5 \ldots .6 . \ldots .7$ Not at all impulsive

* Note: the space between each digit on the item scale represents ten units of measure, e.g. $1 \ldots \ldots \ldots \ldots . \ldots \ldots \ldots . \ldots . \ldots \ldots 4 \ldots \ldots \ldots . \ldots \ldots \ldots 6 \ldots \ldots . \ldots 7)$ 
APP ENDIX C

OPEN-ENDED FORM 
BELOW DESCRIBE THE PERSON UNDER CONSIDERATION AS YOU WOULD EXPECT THAT PERSON TO BE IIKE 
APPENDIX D

IMAGERY QUESTIONNAIRE 
WHILE YOU WERE DESCRIBING THE STIMULUS PERSON DID YOU IN YOUR MIND'S EYE PICTURE ANYONE PERSON(S) AS YOU WERE RESPONDING?

YES NO

IF YOU ANSWERED YES TO THE QUESTION ABOVE, PLEASE INDICATE THE RELATION THAT PERSON IS TO YOU.

Authority FIgure

Parental Figure

Family Relation

Spouse

Boyfriend

Girlfriend

Peer

Mass Media Figure

Other

PLEASE INDICATE THE AGE AND OCCUPATION OF THE REIATIONS YOU CHECKED ABOVE. 
APP ENDIX E

RESPONSE BOOKLET FOR OPEN-ENDED PROCEDURE 
WE WOULD IIKE TO KNOW SOMETHING ABOUT PEOPLES I FIRST IMPRESSIONS. IMAGINE YOU ARE GOING TO MEET SOMEONE FOR THE FIRST TIME AND THE ONLY THING YOU KNOW IN ADVANCE IS THAT SHE IS AN ADULT. WHAT WOULD YOU EXXPCT THIS PERSON TO BE IIKE?

NOW TURN THE PAGE AND FOLLOW THE INSTRUCTIONS GIVEN AT THE TOP OF THE PAGE. TAKE YOUR TIME IN RESPONDING WORKING THROUGH THE BOOKLET. WE REAIIZE THIS MAY SEEM TO BE A DIFFICULT TASK BUT PLEASEI TRY TO RESPOND AS YOU THINK THE PERSON UNDER CONSIDERATI ON WOULD BE IIKE. 
BEIOW DESCRIBE THE PERSON UNDER CONSIDERATION AS YOU WOULD EXXECT THAT PERSON TO BE IIKE 
WHILE YOU WERE DESCRIBING THE STIMULUS PERSON DID YOU IN YOUR MINE'S EYE PICTURE ANYONE PERSON(S) AS YOU WERE RESPONDING?

YES NO

IF YOU ANSWERED YES TO THE QUESTION ABOVE, PLEASE INDICATE THE RELATION THAT PERSON IS TO YOU.

Authority Figure

Parental Figure

Family Relation

Spouse

Boyfriend

Girlfriend

Peer

Mass Media Figure

Other

PLEASE INDICATE THE AGE AND OCCUPATION OF THE REIATIONS YOU CHECKED ABOVE. 
NOW WE WOUID IIKE FOR YOU TO GO THROUGH THESE SAME ITEMS A SECOND TIME. AGAIN IMAGINE YOU ARE GOING TO MEET SOMEONE FOR THE FIRS T TIME AND THE ONLY THING YOU KNOW IN ADVANCE IS THAT HE IS AN ADULT. WHAT WOULD YOU EXPECT THIS PERSON TO BE IIKE?

NOW TURN THE PAGE AND FOLLOW THE SAME INS TRUCLIONS AS BEFORE. 
BELOW DESCRIBE THE PERSON UNDER CONSIDERA TION AS YOU WOUL EXXPET THAT PERSON TO BE ITKE 
WHILE YOU WERE DESCRIBING THE STIMULUS PERSON DID YOU IN YOUR MIND'S EYE PICTURE ANYONE PERSON(S) AS YOU WERE RESPONDING?
YES
NO

IF YOU ANSWERED YES TO THE QUESTION ABOVE, PLEASE INDICATE THE RELATION THAT PERSON IS TO YOU.

Authority Figure

Parental Figure

Family Relation

Spouse

Boyfriend

Gir]friend

Peer

Mass Media Figure

Other

PLEASE INDICATE THE AGE AND OCCUPATION OF THE RELATIONS YOU CHECKED ABOVE. 
APPENDIX F

VAIIDATION QUESTIONNAIRE 
THIS IS A SECOND PART OF A STUDY ON IMPRESSION FORMAIION. WE HAD PREVIOUSLY ASKED A GROUP OF SUBJECIS TO DESCRIBE VARIOUS PEOPLE BY FIILING OUT A RESPONSE FORM. WE WOULD IIKE YOJ TO STUDY THE RESPONSES ON THIS ATTACHED FORM WHICH WERE USED TO DESCRIBE THESE DIFFERENT PEOPLE. THEN ON THE: BASIS OF THESE RESPONSES AND YOUR IMPRESSION, PLEASE ANSWHR THE FOLIOWING QUESTIONS BY MARKING THE APPROPRIATE CIRCIE ON THE IBM CARD.

1. The letter in the upper corner of this page is:
(a)
(b)
(c)
(d)

2. The person described in this form is of what age?
a) $15-19$ years
b) $20-24$
c) $25-30$
d) $30-40$
e) 40

3. How confident are you of your above answer?
a) $0-20 \%$
b) $20-40 \%$
c) $40-60 \%$
d) $60-80 \%$
e) $80-100 \%$

4. The person's occupation is:
a) not working
b) a student
c) blue collar
d) white collar
e) not enough information

5. How confident are you of your above answer?
a) $0-20 \%$
b) $20-40 \%$
c) $40-60 \%$
d) $60-80 \%$
e) $80-100 \%$

6. The person is $a$ :
a) $\operatorname{male}$
b) fema le
c) not enough information

7. How confident are you of your above answer?
a) $0-20 \%$
b) $20-40 \%$
c) $40-60 \%$
d) $60.80 \%$
e) $80-100 \%$

8. This description is:
a) desirable
b) neither desirable nor undesirable
c) undesirable

9. Do you consider this described person as:
7) very well-adjusted
b) adequately adjusted
c) poorly adjusted

d) not enough information 
10. While you were studying this description did you in your mind's eye picture any one person?
a) yes
b) no

11. If you answered yes to the question above which of the following is that person in relation to you:
a) family relation
b) boyfriend or girlfriend
d) other
e) does not apply
c) peer 
APPENDIX G

ITEM ANALYSIS FOR ADJECTIVE CHECKIIST 


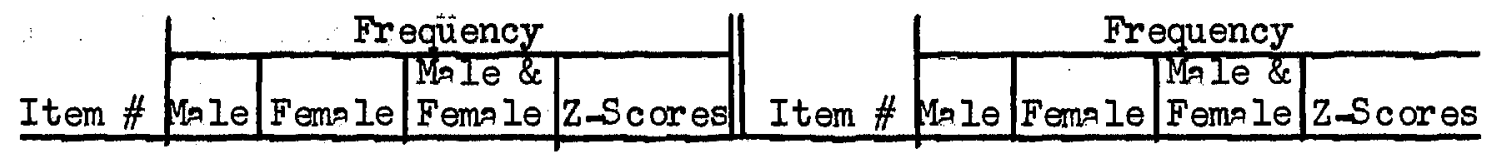

\begin{tabular}{|c|c|c|c|c|c|c|c|c|}
\hline 1 & 6 & 2 & 2.45 & 50 & 13 & 2 & 8 & $2.84+$ \\
\hline 20 & 13 & 35 & 1.02 & 51 & 0 & 0 & 0 & 0.00 \\
\hline 3 & 10 & .17 & 1.00 & 52 & 2 & 0 & 1 & 1.41 \\
\hline 26 & 6 & 25 & $3.53 * \mathrm{M}$ & 53 & 10 & 15 & 9 & 1.00 \\
\hline 2 & 4 & 1 & .82 & 54 & 3 & 0 & 0 & 1.73 \\
\hline 8 & 22 & $1 \overline{4}$ & $2.58 * \mathrm{~F}$ & 55 & 17 & 9 & 5 & 1.57 \\
\hline 21 & 5 & 7 & $3.13 * \mathrm{M}$ & 56 & 5 & 1 & 0 & 1.63 \\
\hline 18 & 16 & 24 & .33 & 57 & 9 & 5 & 4 & 1.07 \\
\hline 3 & 4 & 2 & .37 & 58 & 8 & 1 & 4 & 2.33 \\
\hline 24 & 9 & 32 & $2.60 * \mathrm{M}$ & 59 & 10 & 5 & 4 & 1.29 \\
\hline 11 & 8 & 3 & .68 & 60 & 17 & 12 & 36 & .93 \\
\hline 3 & 5 & 0 & .71 & 61 & 6 & 13 & 3 & 1.61 \\
\hline 21 & 15 & 19 & 1.00 & 62 & 0 & 1 & 0 & 1.00 \\
\hline 9 & 4 & 4 & 1.33 & 63 & 18 & 4 & 17 & $2.98 \times M$ \\
\hline 8 & 4 & 3 & 1.15 & 64 & 16 & 9 & 12 & 1.40 \\
\hline 5 & 16 & 7 & 2.40 & $65^{\circ}$ & 3 & 3 & 5 & 0.00 \\
\hline 5 & 2 & 2 & 1.13 & 66 & 3 & 2 & 1 & .45 \\
\hline 10 & 38 & 28 & $4.04 * F$ & 67 & 6 & 4 & 1 & .63 \\
\hline 5 & 1 & 1 & 1.63 & 68 & 1 & 1 & 0 & 0.00 \\
\hline 1 & 8 & 0 & 2.33 & 69 & 3 & 2 & 1 & .45 \\
\hline 3 & 1 & 0 & 1.00 & 70 & 21 & 4 & 6 & $3.40+$ \\
\hline 0 & 0 & 0 & 0.00 & 71 & 1 & 8 & 2 & 2.33 \\
\hline 12 & 1 & 2 & $3.05+$ & 72 & $\therefore \overline{4}$ & 1 & 1 & 1.34 \\
\hline 8 & 7 & 0 & .25 & 73 & 13 & 10 & 27 & .63 \\
\hline 19 & 15 & 18 & .68 & $7 \overline{4}$ & 0 & 9 & 0 & $3.00+$ \\
\hline 11 & 9 & 44 & .45 & 75 & 14 & 10 & 21 & .82 \\
\hline 3 & 4 & 0 & .38 & 76 & 9 & 1 & 1 & 2.53 \\
\hline 15 & 18 & 8 & .52 & 77 & 3 & 30 & 14 & $4.70 \times F$ \\
\hline 16 & 11 & 13 & .96 & 78 & $1 \longdiv { 4 }$ & 13 & 27 & .19 \\
\hline 8 & 33 & 15 & $3.90 * \mathrm{~F}$ & 79 & 13 & 5 & 9 & $2.82+$ \\
\hline 11 & 24 & 31 & 2.19 & 80 & 18 & 11 & 18 & 1.61 \\
\hline 10 & 9 & 21 & .23 & 81 & 0 & 2 & 3 & 1.41 \\
\hline 12 & 10 & 36 & .43 & 82 & 13 & 17 & 11 & .73 \\
\hline 18 & 11 & 17 & 1.30 & 83 & 11 & 16 & 19 & .96 \\
\hline 5 & 0 & 1 & 2.23 & 84 & 55 & 6 & 0 & 1.80 \\
\hline 4 & 3 & 3 & .38 & 85 & 0 & 4 & 0 & 2.00 \\
\hline 3 & 3 & 2 & 0.00 & 86 & 0 & 46 & 4 & $6.78 * F$ \\
\hline 6 & 8 & 4 & .53 & 87 & 4 & 5 & 0 & .33 \\
\hline 1 & 3 & 0 & 1.00 & 88 & 2 & 16 & 2 & $3.30+$ \\
\hline 8 & 4 & 0 & 1.15 & 89 & 1 & 8 & 0 & 2.33 \\
\hline 27 & 13 & 26 & 2.21 & 90 & 16 & 1 & 2 & $3.64+$ \\
\hline 4 & 6 & 1 & .63 & 91 & 12 & 2 & 7 & $2.67+$ \\
\hline 10 & 13 & 14 & .63 & 92 & 1 & 7 & 1 & 2.12 \\
\hline 12 & 15 & 4 & .58 & 93 & 15 & $1 \dot{4}$ & $2 \overline{2}$ & .18 \\
\hline 17 & 18 & 24 & .17 & 94 & 3 & 3 & 1 & 0.00 \\
\hline 6 & 13 & 1 & 1.60 & 95 & 24 & 7 & $1 \overline{5}$ & $3.05 * \mathrm{M}$ \\
\hline 7 & 4 & 5 & .90 & 96 & 15 & 16 & 45 & .18 \\
\hline 14 & 11 & 16 & .60 & 97 & 2 & 6 & 1 & 1.41 \\
\hline 12 & 11 & 15 & 1 & 98 & 0 & 6 & 2 & 2.45 \\
\hline
\end{tabular}




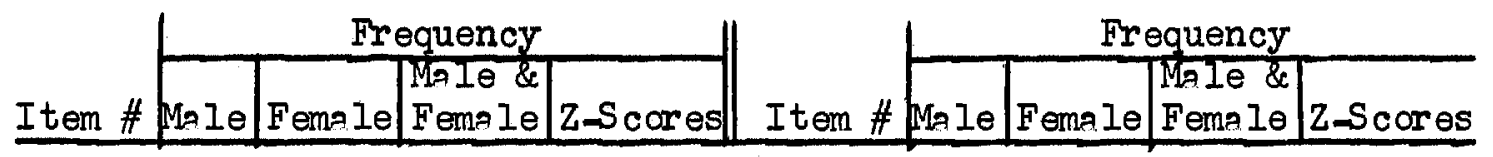

\begin{tabular}{|c|c|c|c|c|c|c|c|c|c|}
\hline 99 & 10 & 15 & 21 & 1.00 & 148 & 20 & 10 & 34 & 1.82 \\
\hline 100 & 7 & 22 & 23 & $2.78 * F$ & 149 & 1 & 5 & 1 & 1.63 \\
\hline 101 & 0 & 2 & 1 & 1.41 & 150 & 3 & 2 & 1 & .45 \\
\hline 102 & 16 & 12 & 34 & .76 & 151 & 6 & 12 & 4 & 1.41 \\
\hline 103 & 16 & 12 & 30 & .34 & 152 & 10 & 8 & 4 & .47 \\
\hline 104 & 2 & 1 & 1 & .58 & 153 & 8 & 6 & 1 & .53 \\
\hline 105 & 33 & 0 & 2 & $5.74 * \mathrm{M}$ & $15 \overline{4}$ & 3 & 17 & 7 & $3.13+$ \\
\hline 106 & 9 & 4 & $I$ & 1.38 & 155 & 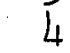 & 8 & $i$ & 1.15 \\
\hline 107 & 1 & 2 & 1 & .58 & 156 & 2 & 2 & 5 & .82 \\
\hline 108 & 2 & 2 & $I$ & 0.00 & 157 & 9 & 14 & 28 & 1.04 \\
\hline 109 & II & 8 & 3 & 1.43 & 158 & 4 & 5 & 2 & .33 \\
\hline 110 & 15 & 15 & 34 & 0.00 & 159 & 5 & 1 & 0 & 1.63 \\
\hline 111 & 12 & $1 \longdiv { 4 }$ & 24 & .39 & 160 & 6 & 5 & 6 & .30 \\
\hline 112 & 6 & 6 & 2 & 0.00 & 161 & 4 & 2 & 0 & .82 \\
\hline 113 & 10 & 10 & 39 & 0.00 & 162 & 12 & 8 & 8 & .89 \\
\hline 114 & 0 & 0 & 1 & 1.41 & 163 & 13 & 0 & 4 & $3.60+$ \\
\hline 115 & 16 & 14 & 27 & .36 & 164 & 12 & 11 & 18 & .21 \\
\hline 116 & 4 & 8 & 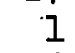 & 1.15 & 165 & 13 & 15 & 18 & .38 \\
\hline 117 & 10 & 11 & 6 & .22 & 166 & 12 & 8 & 14 & .89 \\
\hline 118 & 18 & 5 & .18 & $2.71 * \mathrm{M}$ & 167 & 17 & 9 & 24 & 1.57 \\
\hline 119 & 1 & 7 & 1 & 2.12 & 168 & 12 & 5 & 7 & 1.69 \\
\hline 120 & 5 & 6 & 2 & .30 & 169 & 3 & 0 & 2 & 1.73 \\
\hline 121 & 4 & 9 & 3 & 1.39 & 170 & 13 & 14 & 23 & .19 \\
\hline 122 & 17 & 11 & 19 & 1.13 & 171 & 6 & 15 & 16 & 1.96 \\
\hline 123 & 2 & 0 & 1 & 1.41 & 172 & 1 & 3 & 1 & 1.00 \\
\hline 124 & 15 & 9 & 16 & 1.22 & 173 & 5 & 6 & 3 & .30 \\
\hline 125 & 15 & 4 & 11 & 2.52 & 174 & 15 & 5 & 6 & 2.24 \\
\hline 126 & 0 & 1 & 1 & 1.00 & 175 & 5 & 1 & 0 & 1.63 \\
\hline 127 & 7 & 12 & 5 & 1.15 & 176 & 12 & 5 & 3 & 2.00 \\
\hline 128 & 9 & 5 & 2 & 1.07 & 177 & 12 & 28 & 22 & 2.53 \\
\hline 129 & 2 & 1 & $I$ & .58 & 178 & 15 & 14 & 15 & .23 \\
\hline 130 & 9 & 2 & 5 & 2.11 & 179 & 8 & 22 & 9 & 2.56 \\
\hline 131 & 7 & 2 & 1 & 1.67 & 180 & 9 & 5 & 2 & 1.07 \\
\hline 132 & 11 & 13 & 39 & .41 & 181 & 20 & 6 & 17 & $2.75 * \mathrm{~N}$ \\
\hline 133 & 4 & 6 & 2 & .63 & 182 & 8 & 5 & 4 & .83 \\
\hline 134 & 16 & 10 & 35 & 1.18 & 183 & 7 & 6 & 3 & .28 \\
\hline 135 & 4 & 0 & 1 & 2.00 & $18 \overline{4}$ & 7 & 3 & 2 & 1.26 \\
\hline 136 & 13 & 5 & 10 & 1.89 & 185 & 2 & 6 & 2 & 1.41 \\
\hline 137 & 0 & 2 & 1 & 1.41 & 186 & 14 & 4 & 10 & 2.36 \\
\hline 138 & 4 & 1 & 1 & 1.34 & 187 & 0 & 7 & 0 & $2.64+$ \\
\hline 139 & 9 & 7 & 15 & .50 & 188 & 7 & 0 & 0 & 2.64 \\
\hline 140 & 9 & 20 & 31 & 2.04 & 189 & 0 & 0 & 0 & 0.00 \\
\hline 141 & 2 & 2 & 1 & 0.00 & 190 & 25 & 4 & 10 & 2.52 \\
\hline 142 & 5 & 12 & 6 & 1.69 & 191 & 3 & 9 & 4 & 1.73 \\
\hline 143 & 13 & 6 & 17 & 1.61 & 192 & 0 & 0 & 0 & 0.00 \\
\hline 144 & 5 & 1 & 2 & 1.63 & 193 & 13 & 4 & 13 & 2.18 \\
\hline 145 & 12 & 12 & 15 & 0.00 & 194 & 2 & 4 & 1 & .82 \\
\hline 146 & 13 & 14 & 17 & .19 & 195 & 16 & 11 & 15 & .96 \\
\hline 147 & 56 & 0 & 1 & $7.48 * \mathbb{M}$ & 196 & 11 & 9 & 26 & .45 \\
\hline
\end{tabular}




\begin{tabular}{|c|c|c|c|c|c|c|c|c|c|}
\hline \multirow[b]{2}{*}{ Item } & \multicolumn{4}{|c|}{ Frequency } & \multirow[b]{2}{*}{ Item } & \multicolumn{4}{|c|}{ Frequency } \\
\hline & $\neq \mathrm{Male}$ & Female & $\begin{array}{l}\text { Male \& } \\
\text { Fema le }\end{array}$ & Z-Scores & & \#Male & Fema $1 \mathrm{e}$ & $\begin{array}{l}\text { Male \& } \\
\text { Fema le }\end{array}$ & Z-Scores \\
\hline 197 & 5 & 3 & 2 & .71 & 246 & 10 & 6 & 9 & 1.00 \\
\hline 198 & 2 & 2 & 1 & 0.00 & 247. & 19 & 8 & 11 & 2.12 \\
\hline 199 & 6 & 2 & 2 & 1.41 & 248 & 8 & 2 & 3 & 1.89 \\
\hline 200 & 17 & 12 & 22 & .93 & 249 & 3 & 1 & 0 & 1.00 \\
\hline 201 & 12 & 10 & 41 & .43 & 250 & 3 & 2 & 0 & .45 \\
\hline 202 & 2 & 5 & 0 & 1.13 & 251 & 35 & 5 & 9 & $4.74 * \mathrm{M}$ \\
\hline 203 & 9 & 10 & 2 & .23 & 252 & 7 & 4 & 2 & .90 \\
\hline 205 & 12 & 10 & 15 & .43 & 253 & 1 & 7 & 2 & 2.12 \\
\hline 205 & 12 & 12 & 31 & 0.00 & 254 & 7 & 4 & 6 & .90 \\
\hline 206 & 4 & 7 & 1 & .90 & 255 & 0 & 3 & 0 & 1.73 \\
\hline 207 & 0 & $i$ & 0 & 1.00 & 256 & 3 & 2 & 0 & .45 \\
\hline 208 & 3 & 1 & 1 & 1.00 & 257 & 3 & 3 & 4 & 0.00 \\
\hline 209 & 10 & $\overline{4}$ & 3 & 1.60 & 258 & 11 & 22 & 11 & 1.46 \\
\hline 210 & 5 & 2 & 0 & 1.13 & 259 & 15 & 8 & 18 & 1.46 \\
\hline 211 & 6 & 1 & 3 & 1.89 & 260 & 3 & 1 & 1 & 1.00 \\
\hline 212 & 11 & 4 & 2 & 1.81 & 261 & II & 20 & 20 & 1.62 \\
\hline 213 & 21 & 12 & 27 & 1.57 & 262 & 4 & 11 & 2 & 1.81 \\
\hline 214 & 15 & 12 & 17 & .58 & 263 & 4 & 7 & 2 & .90 \\
\hline 215 & 2 & 6 & 3 & 1.41 & 264 & 0 & $I$ & 1 & 1.00 \\
\hline 216 & 0 & 3 & 1 & 1.73 & 265 & 9 & 17 & 5 & .45 \\
\hline 217 & 2 & 1 & 2 & .58 & 266 & 14 & 13 & 30 & .19 \\
\hline 218 & 8 & $\overline{4}$ & 4 & 1.15 & 267 & 6 & 13 & 6 & 1.61 \\
\hline 219 & 4 & 3 & 1 & .38 & 268 & +2 & 8 & 0 & 1.89 \\
\hline 220 & 8 & $1 \longdiv { 4 }$ & 25 & 1.28 & 269 & 16 & 10 & 14 & 1.18 \\
\hline 221 & 8 & 21 & 13 & 2.41 & 270 & 5 & 5 & 4 & 0.00 \\
\hline 222 & 15 & 7 & 15 & 1.71 & 271 & 10 & 2 & 4 & 2.31 \\
\hline 223 & 1 & $i$ & 0 & 0.00 & 272 & 14 & 13 & 20 & .19 \\
\hline 224 & 14 & 25 & 8 & 1.76 & 273 & 3 & 1 & 0 & 1.00 \\
\hline 225 & 3 & 2 & 0 & .45 & 274 & 1 & 0 & 0 & 1.00 \\
\hline 226 & 15 & 7 & 8 & 1.71 & 275 & 2 & 4 & 1 & .82 \\
\hline 227 & 0 & $i$ & 0 & 1.00 & 276 & 2 & 5 & 0 & 1.13 \\
\hline 228 & 5 & 4 & 3 & .33 & 277 & 1 & 1 & 0 & 0.00 \\
\hline 229 & 9 & 2 & 3 & 2.11 & 278 & 8 & 17 & 31 & 2.20 \\
\hline 230 & 1 & $1 \overline{4}$ & 1 & $3.36+$ & 279 & 5 & 1 & 1 & 1.63 \\
\hline 231 & 5 & 9 & 1 & 1.07 & 280 & 3 & 2 & $\overline{0}$ & .45 \\
\hline 232 & 4 & 11 & 7 & 1.81 & 281 & 3 & 0 & 0 & 1.73 \\
\hline 233 & 12 & 16 & 26 & .76 & 282 & 5 & 5 & 6 & 0.00 \\
\hline 234 & 1 & 0 & 0 & 1.00 & 283. & 0 & 0 & 1 & 0.00 \\
\hline 235 & 0 & 1 & 1 & 1.00 & 284 & 4 & 0 & 0 & 2.00 \\
\hline 236 & 2 & 0 & 2 & 1.41 & 285 & 1 & 4 & 2 & 1.34 \\
\hline 237 & 1 & 2 & 1 & .58 & 286 & 1 & 1 & 1 & 1.00 \\
\hline 238 & $\overline{4}$ & 3 & 3 & .38 & 287 & 11 & 12 & 15 & .21 \\
\hline 239 & 10 & $1 \longdiv { 4 }$ & 26 & .82 & 288 & 1 & 2 & 1 & .58 \\
\hline 240 & 6 & 25 & 10 & $3.41 * F$ & 289 & 1 & 0 & 0 & 1.00 \\
\hline 241 & 9 & 9 & 9 & 0.00 & 290 & 17 & 13 & 14 & .73 \\
\hline 242 & 6 & 2 & 2 & 1.41 & 291 & 5 & 25 & 34 & $3.65 * F$ \\
\hline 243 & 1 & 2 & 0 & .58 & 292 & 3 & 1 & 2 & 1.00 \\
\hline 244 & 4 & 6 & 8 & .63 & 293 & 1 & 2 & 0 & .58 \\
\hline 245 & 7 & 10 & 3 & 73 & 294 & 0 & 2 & 0 & 1.41 \\
\hline
\end{tabular}




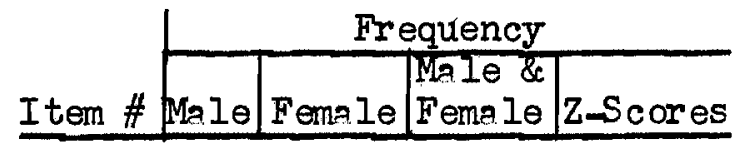

$\begin{array}{lllll}295 & 7 & 16 & 13 & 1.88\end{array}$

$\begin{array}{lllll}296 & 16 & 12 & 17 & .76\end{array}$

$\begin{array}{lllll}297 & 1 & 1 & 0 & 0.00\end{array}$

$\begin{array}{llllll}298 & 18 & 9 & 20 & 1.73\end{array}$

$\begin{array}{lllll}299 & 3 & 9 & 0 & 1.73\end{array}$

$\begin{array}{lllll}300 & 2 & 5 & 2 & 1.13\end{array}$

*M = Male stereotype, $\mathrm{p}<_{4} \mathrm{Ol}$ as well as reaching criterion of 40 percent use by sample

*F = Female stereotype, $\mathrm{p}, 0 \mathrm{Ol}$ as well as reaching criterion of 40 per cent use by sample

$+=$ pe.01, but item did not reach criterion of 40 percent use by semple 
APPENDIX $\mathrm{H}$

ITEM ANA LYSIS FOR STEREOTYPE QUES TIONNAIRE 


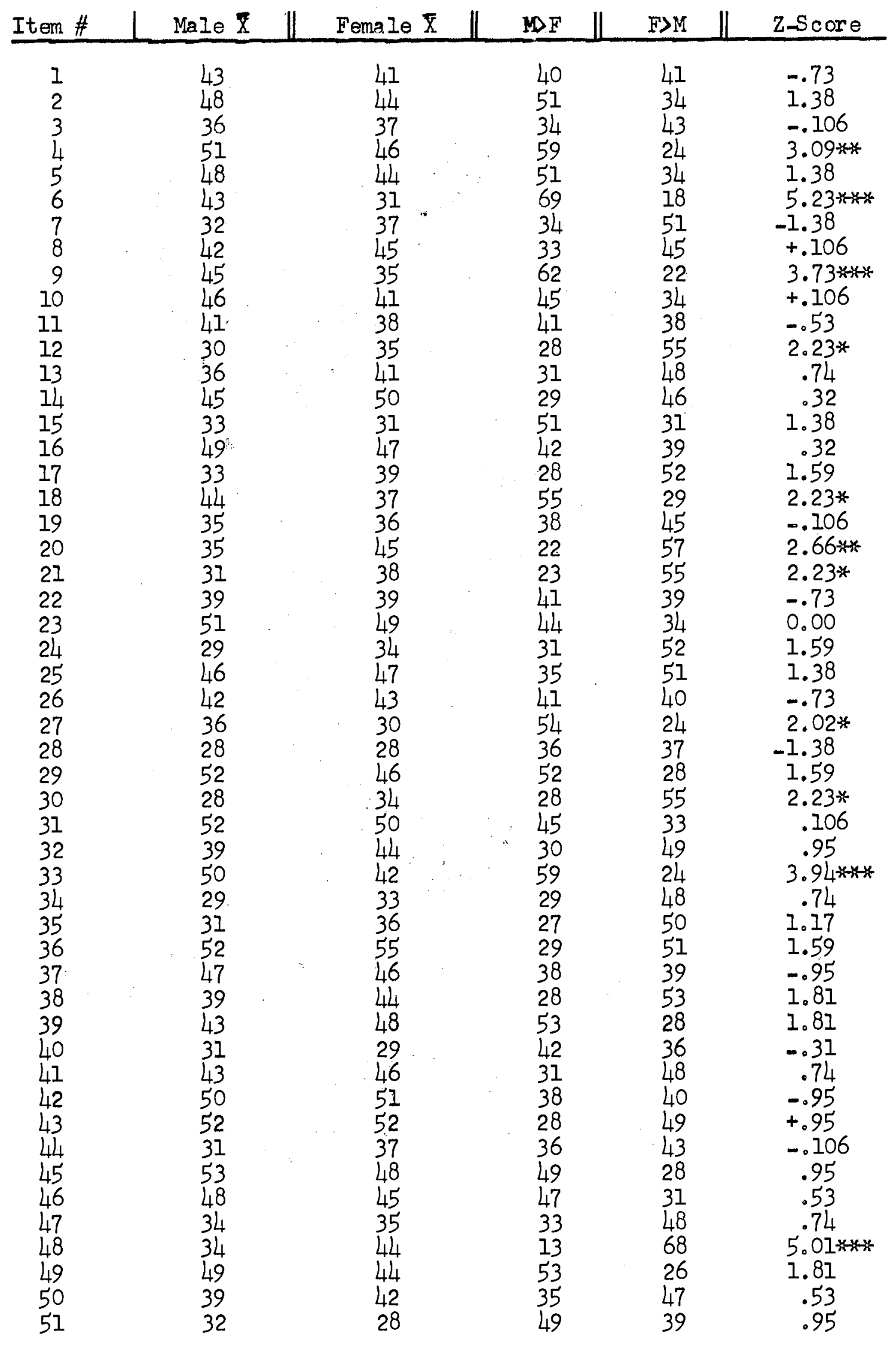




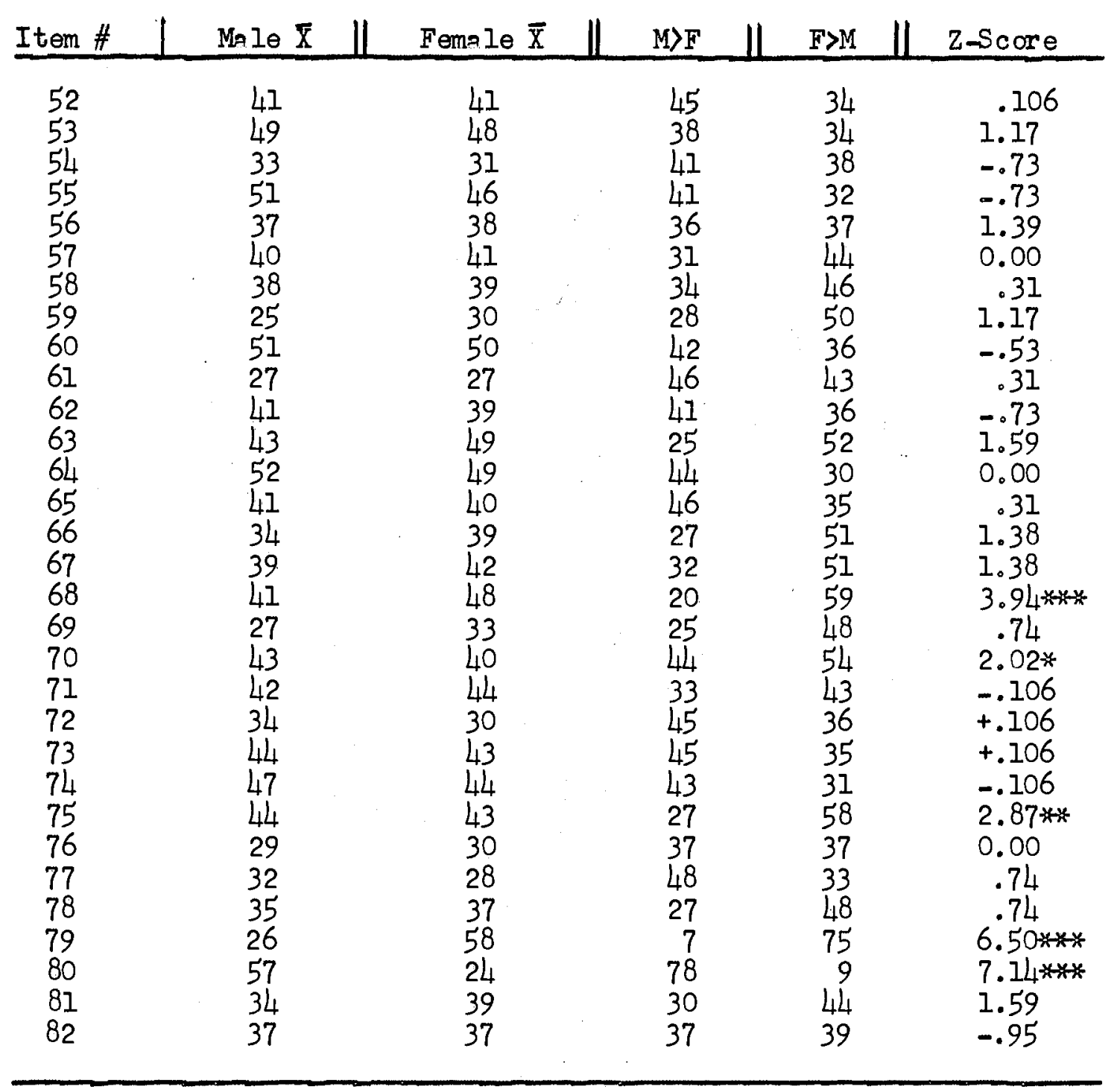

*p $<.05, z=1.90$

$* * 0.01, z=2.58$

$* * * 0<.001, z=3.33$ 


\author{
2 \\ VITA \\ Margie Louise Cowan \\ Candidate for the Degree of \\ Master of Science
}

Thesis: A METHODOLOGICAL STUDY OF SEX STEREOTYPES

Ma jor Field: Psychology

Biographica I:

Personal Data: Born in Duncan, Oklahoma on March 7, 1949, the daughter of Mr. and Mrs. Ansel Cowan, Jr.

Education: Graduated from Vidalia High School, Vidalia, Louisian in 1967; received the Bachelor of Arts degree from Louisian Tech University, Ruston, Louisiana in 1970 with a major in psychology and a minor in English.

Professional Experience: Served as a Graduate Tëaching Assistant in the College of Arts and Science, Oklahome State University, 1970-1972; Craduate Associate of Psychological Guidance Center, 1971-1972; was a National Science Foundation Summer Research Assistant, 1972. 